WIAS Discussion Paper No.2017-003

International Fisheries Access Agreements and Trade

November 24, 2017

Tatyana CHESNOKOVA

Waseda Institute for Advanced Study, Waseda University

Stephanie F. McWhinnie

School of Economics, University of Adelaide

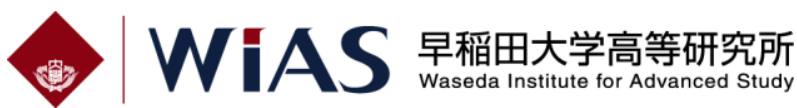

1-6-1 Nishiwaseda, Shinjuku-ku, Tokyo 169-8050, Japan Tel: 03-5286-2460 ; Fax: 03-5286-2470 


\title{
International Fisheries Access Agreements and Trade
}

\author{
Tatyana Chesnokova ${ }^{\dagger}$ and Stephanie F. McWhinnie* \\ This Version: October 2017
}

\begin{abstract}
International fishery access agreements allow fishermen from one country to harvest fish in another country's waters. We empirically examine, using a unique global panel dataset, why countries sign fisheries access agreements with each other and compare these to the characteristics of countries that choose the path of international trade. We show that access agreements and fish exports are driven by two key motives: a pattern of comparative advantage in fishing, which depends on fish stocks and fishing capacities; and gravity factors of economic size and distance. Our results suggest that most gravity factors work similarly for agreements and exports: larger countries that are closer to each other are more likely to sign access agreements or to trade. However, the pattern of advantage is determined differently: source countries with larger fishing capacity are more likely to export fish, while source countries with lower fishing capacity are more likely to sign agreements.
\end{abstract}

Keywords: International fisheries, access agreements, international trade, empirical JEL classification: Q22, Q27, F13, F14, F18

Acknowledgements: We are grateful for comments from participants at the Australian Agricultural and Resource Economics Society Conference, the New Zealand Agricultural and Resource Economics Society, the Australasian Trade Workshop and at seminars at the Universities of Melbourne, New South Wales, Tasmania, Adelaide, Calgary, Waterloo, British Columbia and Oberlin College. We acknowledge financial support from the University of Adelaide.

†tatyana@aoni.waseda.jp. Waseda Institute for Advanced Study, Waseda University, Tokyo, Japan.

*stephanie.mcwhinnie@adelaide.edu.au. School of Economics, University of Adelaide, SA 5005, Australia. 


\section{Introduction}

Fishermen fishing outside their nation's territorial waters has occurred throughout history. In fact, the relative abundance of cod off the North East coast of North America was an important element in the early European settlement of those shores (Kurlansky, 1998) as were the whale stocks in the southern oceans for Australia and New Zealand (Prickett, 2002). The challenge faced by countries with relatively abundant fish stocks is how to take best advantage of providing these fish to consumers in other countries. One way is to use, or develop, their own fishing industry to harvest the fish and then engage in trade. The alternative is to undertake an access agreement to allow fishermen from another country to legally harvest the fish directly. These agreements are popularly seen as being purely exploitative ${ }^{1}$ whereas a World Bank report (Arthur et al., 2014) describes them simply as a type of trade in fishing services. As demand for fish is large, with one-fifth of the world's population relying on fish products as their major animal protein source, and rising, consumption is predicted to rise more than $20 \%$ in the next decade (FAO, 2016), it is important to understand how the economic motives for fishery access agreements differ from those for fish exports.

Our paper is the first to empirically examine, using a unique global panel dataset, why countries sign fisheries access agreements with each other and compare these determinants to the characteristics of countries that choose the path of international trade. We show that access agreements and exports of fish are driven by two key motives: a pattern of comparative advantage in fishing and the gravity factors of economic size and distance. Our results suggest that while the gravity factors work in a similar way for both agreements and fish exports, that is, larger and closer countries are more likely to sign access agreements and trade in fish, the pattern of advantage in fishing is determined differently, with the countries' fishing capacities being the key difference. Thus, our results are consistent with the position of the World Bank report (Arthur et al., 2014) that agreements are functioning as trade in fishing services.

To derive testable predictions for our empirical analysis, we first establish a simple conceptual environment where fishery access agreements and exports of fish are two alternative pathways to provide consumers in a destination country with fish products from the waters of a source country. We outline two key motives for countries signing an access agreement or entering a trade relationship. The first motive of a pattern of comparative advantage in fishing depends on both the fish stock status and the capacity of the country's fishing

\footnotetext{
${ }^{1}$ See for example commentary by Greenpeace (2012) or in the movie The Cove (2009).
} 
industry. The second motive is related to the gravity factors of economic size and distance between countries. Our conceptual environment shows that while the gravity factors are predicted to affect the probability of countries signing an access agreement or engaging in fish trade in a similar way, the pattern of fishing advantage is defined differently for these two alternatives. In particular, our prediction is that the pattern of fishing advantage that makes an access agreement more likely is realized if the source country waters are more abundant in fish and if the destination country has a higher fishing capacity. For the case of fish exports, our prediction is that the type of comparative advantage that increases the probability of trade is realized if the source country fish stocks and the source country fishing capacity are relatively large.

To test our predictions, we construct a unique panel of agreements and trade country-pairyear observations by utilizing data from various sources. We combine data on international fisheries access agreements, fish stock status and fish catch from the Sea Around Us project (Pauly and Zeller, 2015; Zeller et al., 2016) with data on fish trade from the NBER-United Nations Trade Data (Feenstra et al., 2004) and data on gravity country-pair characteristics from the CEPII Gravity Data (Head et al., 2010). Our baseline sample contains 256,163 country-pair-year observations in the period 1962-2000, with 5.7\% having an access agreement and $20.1 \%$ engaging in a trade relationship. We use this data to test our empirical predictions by estimating the importance of the comparative advantage in fishing motive and the importance of the gravity motive.

Our results show that the pattern of comparative advantage in fishing is indeed an important motive for countries signing an access agreement. A higher fish stock status in the source country and a higher fishing capacity in the destination country increase the probability of access agreement. The gravity factors also play an important role: countries with a higher GDP per capita, a larger population and that are closer to each other, are more likely to have a fishery agreement. We explore the robustness of our results by estimating various alternative specifications. We show that our results are not driven only by major distant water fishing nations (DWFN) such as the EU, the US, or Japan, and controlling for historical fishing relationships, while important, does not change our baseline results. We also investigate how the determinants of reciprocal access agreements differ from those of non-reciprocal agreements. Our results suggest that fishing advantage plays an important role for non-reciprocal agreements, while reciprocal agreements tend to be between more similar countries. 
Our predictions for the determinants of fish exports are also supported by the estimation results. A higher fish stock status of the source country and a lower stock status of the destination country increase the probability of fish exports. The notable difference with the estimation results for agreements is that the pattern of fishing capacities is now reversed: a higher fishing capacity of the source country and a lower fishing capacity of the destination country make trade between these countries more likely. The gravity motive is also an important determinant of fish trade: countries with a higher income per capita and that are closer are more likely to trade in fish products. Similar to the analysis of agreements, we explore whether our results are robust to alternative specifications and the difference between reciprocal and non-reciprocal fish exports. We show that, as with agreements, the motives are different: the pattern of advantage in fishing plays a role only for non-reciprocal trade in fish.

Our paper is the first to empirically study access agreements on a global scale. In the resource economics literature, fisheries access agreements have been examined in case studies such as Bonfil et al. (1998), Le Manach et al. (2013), Mallory (2013) and Nichols et al. (2015). These studies allow consideration of the effects of particular agreements on fish stock status and the benefits and costs to source and destination countries and groups within the countries. Case studies though, by their very nature, are unable to systematically distinguish whether the determinants of international relations more generally or fisheries specific comparative advantage are important for fisheries access agreements. ${ }^{2}$

Unlike the resource literature on access agreements, there are several existing papers that examine international trade in fishery products on a global scale, although the focus of these studies is different from ours. One of the issues analyzed in this literature is the relationship between food security and evolution of fish trade flows between developed and developing countries. Asche et al. (2015) and Watson et al. (2017) find that there is an exchange of quality of fish products where developing countries export higher value fish and import lower value fish while the opposite is true for higher income countries. Another important policy issue is whether increasing globalization causes overfishing and depletion of fish stocks. Erhardt (2016) demonstrates that trade openness reduces overuse of fish species in countries with lax governments and does not impact overuse in countries with higher governance levels. There are also multiple case studies of various issues in international trade in fishery products, such as the determinants of fish imports into the United States (Rabbani

\footnotetext{
${ }^{2}$ The broader consequences of international sharing in fisheries have been examined by McWhinnie (2009) and Rus (2012).
} 
et al., 2011; He et al., 2013), the trade forgone due to changes in food safety rules (Disdier and Marette, 2010; Yunus, 2009), international fish market integration (Tveteras and Asche, 2008), product competitiveness (Hoshino et al., 2015; Norman-Lopez et al., 2013) and food safety requirements (Alavi, 2009). Our paper brings threads from both the resources and the trade literature together to conduct a global analysis of the key drivers of agreements and trade.

The rest of the paper proceed as follows. In Section 2, we outline a simple conceptual environment to derive testable predictions for our empirical analysis. The distinctive dataset with which these predictions are tested is described in Section 3. The empirical analysis and results of our agreement and trade incidence estimations are given in Section 4. Finally, Section 5 discusses the conclusions that comparative fishing advantage and gravity factors are important for the alternative pathways of international fisheries access agreements and trade.

\section{Conceptual Environment}

In this Section we outline a simple conceptual environment to derive testable predictions on the determinants of international access agreements and international trade in fish products for our empirical analysis. It is important to note here that our empirical analysis is constrained by the available data on access agreements, which allows us to observe only the incidence of agreements but not the value of catch. Therefore, in our environment we focus on the determinants of incidence of access agreements and fish exports.

Our empirical analysis has a relatively stronger focus on access agreements. This stems from the fact that international trade in fish products has been considered empirically to some degree, as discussed in Section 1, but there is no comprehensive empirical analysis of access agreements. Our conceptual environment, however, incorporates both access agreements and exports of fish products for completeness.

We start with the idea that access agreements and exports of fish products are essentially two alternative pathways to provide consumers in one country, which we call a destination country $d$, with fish products sourced from the waters of another country, which we call a source country s. For simplicity we assume that the benchmark case is autarkic, that is, there is no international relationship between countries $d$ and $s$, and hence the domestic market in the destination country is served by its local fishery. 
Next, we note that there are two key motives for countries signing a fishery access agreement or entering a trade relationship. The first motive is driven by a pattern of comparative advantage in fishing while the second motive is related to gravity factors of size and distance between the countries, commonly used in the empirical trade literature.

The pattern of comparative advantage in fishing depends on the interplay of two different factors. The first factor is positively related to fish abundance in a country's waters. We assume that each country has an exogenously given fish stock, Stock $k_{i}$ with $i \in\{d, s\} .^{3}$ The assumption that a better fish stock status makes fishing easier and decreases the per unit cost of fish production can be derived from a standard bioeconomic model of fishing. For instance, the Gordon-Schaefer model (Gordon, 1954; Schaefer, 1957) has harvest depending on effort and stock in a complementary fashion that, along with non-decreasing marginal cost of effort, gives the result that marginal cost of harvest is decreasing in fish stock. Hence, a larger fish stock creates an advantage in fishing, no matter which country the fishermen are from.

The second factor that affects the direction of fishing advantage is the capacity of the country's fishing industry, Capacity $i$ with $i \in\{d, s\}$, which we assume is also exogenously given. A higher capacity can be thought to influence advantage in fishing via at least two processes. First, if there are scale economies in the fishing industry then a larger industry can increase catch per unit of variable effort in a bioeconomic model like the Gordon-Schaefer model (Gordon, 1954; Schaefer, 1957). Alternatively, in a model of excess capacity, such as Clark and Munro (2003), the fishing industry will grow until rents are dissipated. Thus if there is existing capacity in one country that can move to another fishery elsewhere, it will be cheaper for this existing capacity to harvest than for a new industry to cover the fixed costs of operation to enter. Hence, via either process, existing fishing capacity will lead to advantage in fishing, independent of where the fish stock is harvested from.

Now consider the factors from a standard gravity model which explain bilateral international trade. It is more likely that fish products will flow from the source country to consumers in the destination country if demand in the destination market is sufficiently large, which is positively related to income and population size. In addition, a larger source country economy is more likely to engage in international relations. Finally, fish products will be more likely to flow from source to destination if the countries are closer to each other, geographically and culturally. Clearly, the impact of closeness on access agreements or exports may depend

\footnotetext{
${ }^{3}$ Note that our environment is a simple static set-up where the fish stock status does not depend on the catch. Clearly, fish stock status is endogenous in a richer dynamic model of trade in renewable resources.
} 
upon how closeness is measured as the supply chain functionality will be different for each pathway.

Next, we discuss how the two motives of comparative advantage in fishing and gravity operate for international access agreements and international trade.

\section{International Fishery Access Agreements}

First, let us consider the probability of a fishery access agreement for a pair of countries that currently have no economic international relationships in fish products. Such an agreement allows fishermen from the destination country to catch fish in the source country's waters.

The pattern of comparative advantage that makes such an agreement more likely is realized if the source country waters are more abundant in fish than the waters of the destination country, and if the destination country has a higher fishing capacity than the source country. Hence, we expect the fishery access agreement to take place if $S_{t o c k}$ and Capacity $_{d}$ are

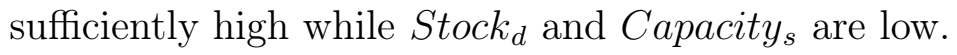

With respect to the gravity factors, a larger economic size of the destination country means that its domestic fishery earns a higher profit and hence will make an agreement more attractive to the destination country. The degree of closeness between the source country and the destination country will depend upon the distance the destination country's fishermen have to travel and the costs of reaching an agreement, which we collectively call the distance costs of foreign fishing. Clearly an agreement is more likely if these foreign fishing costs are sufficiently low.

Empirical Prediction 1 The probability that an international fishery access agreement exists between a source country and a destination country:

(a) increases (decreases) with the fish stock status of the source (destination) country and decreases (increases) with the fishing capacity of the source (destination) country;

(b) increases with the economic size of the destination country and decreases with the distance costs of foreign fishing.

\section{International Trade of Fish Products}

Next, consider the probability that two countries use the alternative pathway of trade to provide fish from the source country to consumers in the destination country, that is exports of fish products from country $s$ to country $d$. 
In this case, the source country needs to have a sufficiently strong comparative advantage in fish products to be an exporter of fish. As in the case of access agreements, the higher is the fish stock status in the source country, the more efficient is fishing in the source country waters and, hence, exports from source to destination are more likely. In contrast, however, the higher is the fishing capacity of the source country's industry and the lower is the fishing capacity of the destination country, the more efficient is the source country fishing industry relative to the fishing industry in the destination country. Hence, we expect exports from the

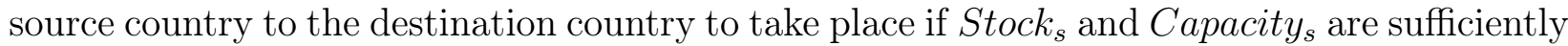

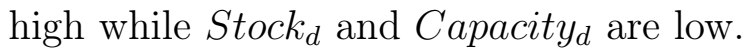

Turning to the gravity factors, as with agreements, a higher economic size of the destination country leads to a higher demand for fish products and hence makes a trade relationship more likely. A higher economic size of the source country means that the total fishery output in the source country is large, which also makes exporting more likely. In the case of trade, it is the source country which must now incur the distance costs of exporting the fish products to consumers in the destination country. Clearly lower distance costs of trade will make trade relationship between two countries more likely.

Empirical Prediction 2 The probability that a source country exports fish products to a destination country:

(a) increases (decreases) with the fish stock status of the source (destination) country and increases (decreases) with the fishing capacity of the source (destination) country;

(b) increases with the economic sizes of the source country and the destination country and decreases with the distance costs of trade.

Our empirical predictions are essentially a variation of a gravity equation, that is a model of bilateral interactions in which economic size and distance effects enter multiplicatively, augmented with determinants of comparative advantage in fishing. Gravity equations have been used as a workhorse for analyzing the determinants of bilateral trade flows, as well as other types of flows and interactions between countries, for 50 years since being introduced by Tinbergen (1962). ${ }^{4}$ Most of the gravity literature explores the determinants of the volume of bilateral flows between countries. However, the fact about half of the country pairs do not trade with one another, led to an emerging trade literature which emphasizes the importance of studying the incidence of zero trade flows. Helpman et al. (2008) utilize a Heckman-based approach to zero trade flows which involves a first stage probit estimation of the probability

\footnotetext{
${ }^{4}$ See Head and Mayer (2014) for an extensive discussion of the gravity literature.
} 
of positive trade incidence between a pair of countries. Their results show that the very same variables that impact export volumes also impact the probability of exports, that is, zero trade flows are more likely between distant and/or small countries. ${ }^{5}$

There are two distinctive important points to make for our analysis.

First, in our conceptual environment, we note a crucial point that comparative advantage is not uniquely defined when there is more than one input and inputs are potentially mobile. In the case of fishing, comparative advantage is related to both the natural resource and its extractive industry. The ability to separate the contribution of two key components of production, fish stock and fishing capacity, is important in international fisheries but it also has implications for other industries where production can be separated into components.

Second, it is also important to highlight that there are likely to be some common factors in determining both the distance costs of foreign fishing and the distance costs of trade. For example, a larger physical distance between two countries reduces the probability of both access agreements and trade. However, there are also likely to be some factors that influence distance costs of a particular type of international transactions in fish products but have very limited influence on the distance costs for the other type. For example, if two countries share a maritime border, then fishermen can move directly from one fishing ground to another, so, holding distance equal, this is likely to reduce distance costs associated with the foreign fishing more than reducing distance trade costs. Hence, the alternative pathways do have some similar drivers but might also have important differences depending upon where and how often international transactions occur. In our empirical analysis we use various variables to measure geographical and cultural distance between countries to understand how these varying characteristics of closeness may impact upon different types of international product flow relationships in different ways.

\section{Data and Key Variables}

Our empirical analysis requires data on a variety of components. As such, we combine data from multiple sources: data on international fisheries access agreements, fish stock status and fish catch from the Sea Around Us project (Pauly and Zeller, 2015; Zeller et al., 2016); data on fish trade from the NBER-United Nations Trade Data (Feenstra et al., 2004); and data on gravity country-pair characteristics from the CEPII Gravity Data (Head et al., 2010). Each

\footnotetext{
${ }^{5}$ Baldwin and Harrigan (2011) find a similar pattern of zeroes using the US product-level trade data.
} 
of these components and the key variables are described below.

\subsection{Fisheries Access Agreements}

The dataset on agreements from the Sea Around Us project (Pauly and Zeller, 2015; Zeller et al., 2016) includes countries in the agreement, agreement type (non-reciprocal, reciprocal, multilateral or unknown) and years in force from 1950-2007. ${ }^{6}$ Access agreements establish the rules for one nation to fish in another nation's waters. These agreements are typically bilateral, with some exceptions, for instance, agreements that have the European Union acting as a single entity and the agreement between the United States and the Pacific Islands Forum Fisheries Agency (FFA). ${ }^{7}$ Access agreements come in a variety of forms: some set exact limits on specific species, others allow access to vessels that traditionally harvested in areas prior to the extension of exclusive economic zones, and others grant blanket access rights. In return for access rights, the harvesting countries may reciprocate with access to their own waters, provide fisheries science and development funds, build ports or undertake fisheries joint ventures, or simply pay cash. The contracts generally have a short (one- to five-year) timeframe and the source country retains the right to manage the fishery optimally, if they so desire.

Details regarding the exact degree of access and compensation are generally not available. Therefore in our empirical analysis the dependent variable is a binary measure of whether there exists a fisheries access agreement between a source country $s$ and a destination country $d$ in a given year $t$ :

$$
A_{s d t}= \begin{cases}1, & \text { if there is an agreement between countries } s \text { and } d \text { in year } t \\ 0, & \text { otherwise. }\end{cases}
$$

Figure 1a depicts the number of access agreements over time globally. The number of agreements increase across the 1970s and the 1980s, with the peak in early 1990s when more than 500 access agreements took place globally. Figure $1 \mathrm{~b}$ depicts the number of destination and source countries over time which represents the extensive margin of the change in the global number of agreements. From the late 1970s until early 1990s there is a pronounced increase in the number of participating countries. The likely reason for the increase in

\footnotetext{
${ }^{6}$ If listed as unknown we conservatively code it as non-reciprocal.

${ }^{7}$ The database codes each country within the EU having an agreement with outside parties if the agreement is negotiated under the common fisheries policy. Similarly, each country in the FFA is coded as having an agreement with the USA. We examine this further in the empirical section.
} 
agreements is an anticipation of the United Nations Convention on the Law of the Sea (1982), which extended national property rights out to 200 nautical miles from shore. Likely causes of the decrease in agreements since the mid-1990s are the rising concerns about fish stock decline and an increase in domestic fishing capacity in some countries.

\section{Major Access Agreements}

To provide some further context, we briefly describe some major access agreements which involve three key players in the global fishing industry: the European Union, the United States, and Japan.

The EU has a network of agreements in the Atlantic Ocean, the Indian Ocean and more recently in the Pacific. These agreements mostly target tuna and tuna-like species. Across the period 1980-2012, the EU had agreements with 20 countries allowing for fishing capacity, as measured by authorized gross registered tonnage, to increase 20-fold. Most of the EU agreements with non-EU countries were not reciprocal and include a financial compensation to the source country, where the payment is based on the number and type of vessels for a specified period of time. The financial compensation varies greatly between the different countries and species and gives rise to approximately $8 \%$ of EU vessels' catch. In 2016, the total EU payments were approximately $€ 130$ million (European Commission, 2016). EU members do, however, have a history of reciprocal agreements with each other, even prior to the Common Fisheries Policy. For instance, France had reciprocal agreements with both Spain and the United Kingdom whereby vessels from Spain or the United Kingdom were permitted to fish in French waters and vice versa.

The US has a major multilateral agreement with 17 Pacific Island countries through Forum Fisheries Agency (FFA). This agreement targets only tuna and includes a fixed amount of financial compensation. The first agreement came into effect in 1988 for an initial period of five years and was extended twice with ongoing negotiations to extend until a new agreement was signed to cover the period 2017-2022. In 2017, the US flagged purse seine vessels were to be offered the right to fish up to 4,150 days in the region in return for a payment worth up to US $\$ 70$ million made up jointly of industry fees and US government contributions (Forum Fisheries Agency, 2016; United States of America, 2016). The US has also a history of bilateral, and some reciprocal, fisheries agreements with Canada, including the 1985 Pacific Salmon Treaty and its antecedent, the International Pacific Salmon Fisheries Commission established in 1937 (Pacific Salmon Commission, 2016). 
Japan has access agreements in the Atlantic, Indian and Pacific Oceans that target mostly high-value tuna and are not reciprocal. The Japanese fleet usually fishes under private access agreements negotiated between the private sector associations and the governments of the source countries. Japanese agreements are not open to the public, therefore there is no information on catch limits and number of vessels. Our panel of data also includes years where Japan had reciprocal agreements with China, Korea and the USSR.

\subsection{Incidence of Fish Trade}

To construct our second dependent variable, fish trade incidence, we use data on trade flows in fish products from the NBER-United Nations Trade Dataset (Feenstra et al., 2004).

This dataset contains bilateral trade data by commodity for the period 1962-2000. The data are organized by the 4-digit Standard International Trade Classification. First, we aggregate the data on value of exports of all fish-related products (with 4-digit SITC=03**) from the source country $s$ to the destination country $d$ in year $t$. Then, we create a binary variable which indicates whether there are exports of fish-related products from country $s$ to country $d: 8$

$$
T_{s d t}= \begin{cases}1, & \text { if there are exports from country } s \text { to country } d \text { in year } t \\ 0, & \text { otherwise. }\end{cases}
$$

Analogously to Figures $1 \mathrm{a}$ and $1 \mathrm{~b}$ for the incidence of fisheries access agreements, Figures $2 \mathrm{a}$ and $2 \mathrm{~b}$ depict the incidence of fish exports globally and the number of exporting and importing countries over time. Of interest is the sharp drop in the number of trade pairs in 1984 . Upon examination, the data indicates that the drop in pairs is due to member countries of the European Union reducing the number of trade partnerships outside of the EU. ${ }^{9}$ This is likely to be explained by the 1983 agreement establishing the new generation Common Fisheries Policy (European Communities, 1983) in combination with the common organization of the market in fishery products, effective from 1982 (European Communities, 1981). Given the limited impact on the number of countries importing and exporting fish products globally seen in Figure 2b, a fairly constant total value of EU trade, and a low value of the partnerships

\footnotetext{
${ }^{8}$ To account for changes in product definitions or mismeasurement, we also considered a specification with trade incidence equal to one if the value of exports was larger than $\$ 5000$, which did not affect the results. The estimation results are not reported but are available upon request.

${ }^{9}$ We use the name European Union for consistency throughout the paper but note that the relevant organisation in 1984 was the European Economic Community.
} 
dropped, it seems that the EU countries responded to the more coordinated fisheries policy by dropping smaller trade partners, at least in the short term. ${ }^{10}$ In our empirical analysis, we control for any Common Fisheries Policy effects by considering a corresponding indicator variable, as our sample does include the EU countries and the discussed time period.

\subsection{Comparative Advantage in Fishing}

Our empirical predictions state that two components measuring the extent of fishing advantage, fish stock status and fishing capacity, are key factors in explaining the likelihood of countries signing a fishery access agreement or trading in fish products. We use the marine trophic index as a measure of fish stock status and the past total catch by a fishing country as a proxy for fishing capacity, both from the Sea Around Us project (Pauly and Zeller, 2015).

First, we describe how we construct a variable to measure the fish stock status using the marine trophic index. The marine trophic index was originally developed by Pauly et al. (1998) and is one of eight measures chosen by the Conference of the Parties to the Convention on Biological Diversity (2004) as an indicator of biodiversity loss. The index is constructed back to 1950 as the following:

$$
M T L_{i t}=\frac{\sum_{z} T L_{z} Y_{z i t}}{\sum_{z} Y_{z i t}},
$$

where $T L_{z}$ is the trophic level of species (or species group) $z$ and $Y_{z i t}$ is the landings of species $z$ in country $i$ in time $t$. The trophic level of species $z$ indicates where this species is in the food chain. A value of one is given to plants and detritus, a value of two to herbivorous fish who consume value one species, a value of three to fish that eat herbivorous fish, and so on. Fish typically have a trophic level between two and four.

Pauly et al. (1998) showed a smoothly declining trend for $M T L$ in most areas. Based on the assumption that the relative abundance of species in the landing data is correlated with the relative abundance of the same species in the ecosystem, these findings are interpreted as representing a decline in the abundance of high-trophic-level fishes relative to low-trophiclevel fishes. This implies that there is 'fishing down the marine food web' and reduction in biodiversity. Hence, the marine trophic index can be used as a proxy of the measure of ocean area health. From an economic perspective, the $M T L$ may be thought of as representing the status of the economically exploitable stock.

Given its ecological focus, the Sea Around Us stock status measures are reported by ocean

\footnotetext{
${ }^{10}$ The value of the EU partnerships that were dropped in 1984 made up $0.2 \%$ of all 1983 trade. While the total value of the EU trade fell by $3.3 \%$ from 1983 to 1984 , it rose by $13.8 \%$ in 1985 .
} 
area, rather than simply by country. For instance, the east, west and arctic regions of Canada and the Pacific and Caribbean regions of Central American countries like Costa Rica and Nicaragua are reported separately. To match with the economic variables that are based on terrestrially-defined countries, we aggregate the $M T L$ of each sub-national region using the proportions of catch as weights. ${ }^{11}$ In our analysis, we use the marine trophic index calculated at the country level as our measure of country $i$ 's aggregate fish stock status in time $t$ :

$$
\text { Stock }_{i t}=M T L_{i t}
$$

Next, we use data on the past total catch by a fishing country as a measure of fishing capacity. The Sea Around Us project (Pauly and Zeller, 2015) reports catch from 1950 both by the source area where fish is caught and by the country of the fishermen performing the fishing. We calculate the total tonnes caught by fishermen from each country. Then, we use ten-year lags of total tonnes caught as a measure of the harvesting capacity of each country $i$ :

$$
\text { Capacity }_{i t}=\text { Total Tonnes Caught } \text { Tit-10 }_{\text {. }}
$$

Contemporaneous catch could be jointly determined by capacity and by existence of access agreements and fishing industry capital is highly durable nature. Therefore, we use ten-year lags as a globally consistent and comparable measure of current fishing potential.

\subsection{Gravity Variables}

To account for the standard gravity variables used in the trade literature, we use data on country-pair characteristics from the 2017 version of the CEPII Gravity Data (Head et al., 2010). The dataset covers pairs of countries globally, for the period 1948-2015.

Our conceptual environment predicts that the economic size of each country and the distance between two countries are important determinants of both access agreements and trade. We use data on GDP per capita and population to account for the economic size of the countries. ${ }^{12}$ To control for distance, we include several standard variables, augmented to account for maritime closeness. Our measures of geographic closeness include: population weighted bilateral distance between countries $s$ and $d$; an indicator variable for countries

\footnotetext{
${ }^{11}$ We also generated $M T L$ for the USSR and Yugoslavia by aggregating over the relevant countries prior to 1991 or 1992 as relevant.

${ }^{12}$ An alternative version using GDP rather than GDP per capita and population is also considered.
} 
sharing a land border; and an indicator variable for the pair of countries sharing a maritime border. ${ }^{13}$ Our measures of cultural closeness between the pair of countries include indicator variables for being members of the same free trade area, having the same currency, ever being colonized by the other or by the same third country, having a common legal origin, having the same official language, and sharing a major religion. ${ }^{14}$

\subsection{Summary Statistics}

Our baseline sample includes all source and destination countries that ever had at least one international access agreement with any other country and ever had trade in fish products with any other country in the time period 1962-2000. ${ }^{15}$ We use this as our universe throughout to have a consistent set of country-pairs to estimate both the determinants of access agreements and the determinants of fish exports. ${ }^{16}$

Combining data from such a variety of sources has left us with 256,163 country-pair-year observations in our baseline sample. There are 14,571 country-pair-year observations that have an access agreement, $A_{s d t}=1$, which is $5.7 \%$ of all observations. There are 51,437 observations with positive fish product trade, $T_{s d t}=1$, which is $20.1 \%$ of observations.

Table 1 provides a list of the main variables used in this paper. Table 2 shows the summary statistics by whether or not a country-pair-year combination has an access agreement (the first and the second columns), by whether or not a country-pair-year combination has positive fish trade (the third and the fourth columns), and for the full baseline sample (the last column).

Casual observation shows that capacity is higher for countries with access agreements and for countries that trade in fish products, particularly for destination countries in the country pairs with access agreements and for countries that are exporters of fish products. The

\footnotetext{
${ }^{13}$ The indicator variable for countries sharing a maritime border is constructed by authors. We thank Kofi Otumawu-Apreku for providing valuable research assistance on this point using information from the Sea Around Us Project (2015) and the Flanders Marine Institute (2014).

${ }^{14}$ We drop all "countries" that are still colonies as they typically do not have consistently reported measures of access agreements. This means that we are likely to be underestimating the number of access agreements. For some colony-colonist relationships this will be unfair as the colony may be extremely autonomous with respect to fisheries management and should therefore be considered as separate. However, we had to draw the line somewhere as some states or islands that are part of the same country are also quite autonomous with respect to fisheries management.

${ }^{15}$ The full universe of possible pair-year combinations is greater than our baseline sample as we exclude countries that never had agreements with anyone. This is because landlocked Lesotho not having a fisheries access agreement with landlocked Austria is different than New Zealand not being a source country to Costa Rica. This universe definition issue also arises in the trade literature where Australia not importing apples from Iceland stems from different reasons than Australia not importing apples from New Zealand.

${ }^{16}$ In our empirical analysis, we address a potential concern of sample selection issue by reestimating our empirical model for alternative samples.
} 
gravity variables indicate that, on average, countries that have access agreements or trade in fish have higher GDP per capita and are more likely to have a shorter distance between them, share a maritime border or a land border, be a part of the same regional trade agreement, have been in a colonial relationship in the past, and share a religion or currency.

\section{Empirical Analysis}

Our goal in this section is to test the Empirical Predictions from Section 2 by estimating the importance of the comparative advantage in fishing motive, that is, the interplay of the stock abundance and the fishing industry capacity, and the importance of the gravity motive, that is, the economic size and distance effects.

\subsection{Estimating Equation}

Our main estimating equation relates the existence of an access agreement $\left(A_{s d t}\right)$ or a trade relationship $\left(T_{s d t}\right)$ between the source country $s$ and the destination country $d$ in time period $t$ to fish stock status, fishing industry capacity, and to gravity variables:

$$
\operatorname{Pr}\left(X_{s d t}=1\right)=\alpha_{0}+\beta^{\prime} F_{s d t}+\gamma^{\prime} G_{s d t}+\alpha_{S} I_{s}+\alpha_{D} I_{d}+a_{T} I_{t}+\varepsilon_{s d t},
$$

where $X_{s d t}$ is a generic representation of the dependent binary variable, which is either $A_{s d t}$ or $T_{s d t}$. As our dependent variables are binary and equal to either zero or one, we estimate a probit model.

Equation 1 includes a vector of explanatory variables related to the pattern of fishing comparative advantage, denoted by $F_{\text {sdt }}$, which consists of variables $\log$ Stock and $\log$ Capacity for the source country and for the destination country. Equation 1 also includes a vector of explanatory gravity variables, denoted by $G_{s d t}$, which consists of variables $\log G D P /$ capita, log Population, log Distance, Maritime Border, Land Border, Legal, Religion, Colony, Common Colonist, FT A, Currency Union and Language, as described in Table $1 .{ }^{17}$

In estimating a gravity equation, it is essential to control not just for bilateral resistance, that is the distance barrier between a pair of countries, but also to control for multilateral resistance, that is the distance barriers that each country faces with all its trading partners. ${ }^{18}$

\footnotetext{
${ }^{17}$ Note that we use a one-year lagged values of Stock, GDP/Capita and Population variables in our estimations, as defined in Table 1.

${ }^{18}$ See Anderson and van Wincoop (2003) for more on the importance of controlling for multilateral trade resistance.
} 
Following the modern approach used in the trade literature, we include a full set of fixed effects for source and destination countries, denoted by $I_{s}$ and $I_{d}$. This approach does not involve strong structural assumptions on the underlying model as fixed effects will account for any unobservables that shape each country's position as either a source or a destination country. Using fixed effects also yields consistent estimates. In addition, we include year fixed effects, denoted by $I_{t}$, and cluster the error term at the country-pair level. ${ }^{19}$

\subsection{Results: International Fisheries Access Agreements}

We begin by estimating Equation 1 with access agreement incidence, $A_{s d t}$, as the dependent variable.

\section{Agreements: Baseline Specification}

The estimation results of our baseline specification are reported in Table 3 where the estimated coefficients are in the first column and the marginal effects are shown in the second column. For indicator variables, (d) indicates that the marginal effect is a change from 0 to 1.

First, let us consider the estimated coefficients of the fishing comparative advantage variables. The coefficient on the stock status of the source country is positive and statistically significant. As the overall probability of an agreement existing in the data is $5.7 \%$, the 0.0036 marginal effect of the mean tropic level of the source country rising by one increases the probability of an agreement by $6.1 \%$. Our results show that a higher stock status in the destination country is also positively and significantly associated with having an agreement, but the coefficient is only two-fifths as large in magnitude. The coefficient on fishing capacity of the destination country is positive and significant, as predicted by our conceptual environment. That is, a larger industry capacity of the source country increases the likelihood of being in an agreement. Capacity of the source country has no statistically significant impact. These results support our Empirical Prediction 1(a) that the resource abundance in the source country and fishing capacity of the destination country are important drivers of access agreements.

Next, we consider the estimated effects of the gravity variables. The estimated coefficients on the economic size characteristics of the destination country are positive and statistically significant, that is, countries that have higher GDP per capita and that are more populous are

\footnotetext{
${ }^{19}$ As our data set spans many years, it would be preferable to include time-varying fixed effects for source and destination countries. However, in this case it would be impossible to estimate the effects of all timevarying country-specific variables of our interest such as fish stock status, fishing capacity or GDP per capita.
} 
more likely to enter access agreements as destination countries. We also find that economically larger source countries, both in terms of GDP per capita and population, exhibit a positive relationship with having an agreement, but the magnitude of the estimated coefficients for the destination country dominates. The coefficients on the measures of costs of foreign fishing typically enter as expected. That is, being less geographically distant, sharing a maritime border, having a common legal origin or common religion, being a past colony and being part of the same trade agreement are positively related to having an access agreement. Hence, these empirical results support our Empirical Prediction 1(b) that the gravity factors are important determinants of fishery access agreements.

Interestingly, we find that sharing a language is negatively associated with having an access agreement while having a land border or a common currency has no statistically significant impact. These findings could be explained in the following way. Under the access agreement, the transportation of the product is all by sea, hence sharing a land border is not as important as sharing a maritime border. Also, apart from the agreement itself, all transactions along the journey from fish-in-the-ocean to filet-on-a-plate can be conducted in the currency and language of the destination country. This eliminates any currency and language barriers between harvesters or producers and consumers. Hence, these variables have less of an impact on the costs associated with foreign fishing. We contrast this with results for fish trade in the next subsection.

\section{Major Access Agreements}

As discussed in Section 3.1, the European Union is an important organization in the analysis of fishery access agreements as the member countries negotiate access agreements under the Common Fisheries Policy (CFP). To control for this, we create an indicator variable, $E U C F P$, that equals one if the country-pair-year had at least one agreement covered by the Common Fisheries Policy. The estimation results are reported in the third column of Table 3. The coefficient on the CFP variable is positive and statistically significant. All other variables retain the same sign and significance and have similar magnitudes as the benchmark specification.

Similarly to the EU, the South Pacific Forum Fisheries Agency (FFA) countries also negotiate access agreements multilaterally as a group. We reestimate our equation with an indicator variable that equals one if the source country is one of the FFA countries. This indicator variable does not have a statistically significant coefficient, however, while all other 
variables have the same sign and statistical significance levels as in the baseline estimation. In addition to the EU and the FFA countries, there are several major distant water fishing nations (DWFN) - Japan, Russia, South Korea, Ukraine, USA and, previously, the USSR - who send significant fleets to access fishing grounds in the high seas and other countries waters. To control for any effects specific to those nations, we create an indicator variable that equals one if the destination country is one of the aforementioned major DWFN. Again, inclusion of this control variable does not change the results in our baseline estimation and nor does this indicator variable have a statistically significant coefficient. ${ }^{20}$ It is not surprising to have statistically insignificant coefficients on these indicator variables as our specification already includes source country and destination country fixed effects. These results indicate that our baseline results are not driven by only the EU, the FFA or major DWFN countries.

\section{Historical Fishing Relationships}

Next, we explore the effect of an important policy change for international fisheries (and other marine resources) that occurred in 1982 when the United Nations Convention on the Law of the Sea (UNCLOS, 1982) extended jurisdiction from a usual three to a 200 nautical mile exclusive economic zone around a nation. We would expect that the number of agreements would rise after 1982 as now an agreement is needed to legally harvest in another country's economic zone. Interestingly, we observe multiple access agreements prior to 1982. This could indicate that a historical relationship between the source and destination countries may be an important determinant of these countries having access agreements after 1982. We use this information to create an indicator variable, Agt Prior $1982_{\text {sdt }}$, which is equal to one if there was an agreement between countries $s$ and $d$ prior to 1982 and if the observation year, $t$, is after 1982 and zero otherwise. The results of accounting for the UNCLOS are reported in the last column of Table 3. The coefficient on Agt Prior $1982_{\text {sdt }}$ is positive and statistically significant, which suggests that having a historical fishing relationship is an important determinant of two countries signing an access agreements after the UNCLOS extended the jurisdiction of the exclusive economic zone. The coefficients on all other variables retain the same signs and statistical significance as in the baseline estimation, except that the negative coefficient on the fishing capacity of the source country becomes significant at $10 \%$ level, thus reinforcing our prediction regarding the importance of the pattern of fishing advantage.

\footnotetext{
${ }^{20}$ Estimation results with FFA Source and DWFN indicators are not reported but are available upon request. We also estimate an alternative specification with all three indicator variables included, which has similar results.
} 
We also considered whether having any other access agreement makes a country more likely to have an agreement. Controlling for the number of agreements that each of the source and destination countries has in that year yields a positive and significant effect but does not change the signs and significance of other variables. ${ }^{21}$

\section{Reverse Causality and Sample Selection}

Our empirical predictions are that a higher fish stock status in the source country will increase the likelihood of agreements or trade. Some causality could, however, operate in reverse: having an agreement could potentially affect the stock status in the source country. If this were true, having an agreement would mean that more fishing is done in the source country, which therefore could lead to a lower stock status in the source country. In this case we would observe a negative relationship between access agreement incidence and the source country's stock status. However, our empirical results above show that the observed relationship is in fact positive. This indicates that the potential issue of reverse causality is either not important or, at least, is not large enough to overturn our results.

We do explore the potential problem of reverse causality a bit further. Ideally, one would do a counterfactual analysis of what stocks would be like in the absence, or presence, of agreements or trade. As we clearly do not have such counterfactual observations, we address this by estimating an alternative specification using ten-year lag on stock status. The tenyear lag is chosen to match the ten-year lag measure of catch capacity and because current agreements or trade should not have an impact on past stock status. The results are reported in the first column of Table 4. The magnitude of the coefficient on the ten-year-lagged stock status of the source country is now smaller but the coefficient is still positive and statistically significant. The coefficient on the stock status of the destination country is now statistically insignificant. All other coefficients are similar to the baseline specification.

Another potential estimation concern is a sample selection issue. Our baseline sample contains all source and destination countries that ever had an agreement with any other country and ever had trade in fish products with any other country in the period 1962-2000. We use this as our universe throughout to have a consistent set of country-pairs to estimate both the determinants of access agreements and the determinants of fish exports. It does, however, mean that some countries that had an agreement but did not have trade, or vice versa, were not included. In particular, the NBER-United Nations Trade Data (Feenstra

\footnotetext{
${ }^{21}$ The estimation results are not reported here but are available upon request.
} 
et al., 2004) does not report some smaller island countries separately so they are excluded due to lack of trade data. To investigate whether the baseline results are driven by our sample selection, we reestimate Equation 1 using a larger sample of agreements data, that is, a sample of 299,389 observations that includes all countries that ever had an agreement, irrespective of whether they ever had trade. The results are reported in the second column in Table 4. The magnitudes, signs and statistical significance of the estimated coefficients are the same as in our baseline estimation so we focus on estimations using our baseline sample.

\section{Reciprocal versus Non-Reciprocal Agreements}

Finally, our database of access agreements includes non-reciprocal and reciprocal agreements, which are potentially of a different nature. We now consider different measures of agreements by considering specifications with only non-reciprocal and with only reciprocal agreements to explore whether the motivation for reciprocal agreements is different than the motivation for non-reciprocal agreements. For instance, reciprocal agreements may be made not due to overall stock status differences but to allow for species-specific specialization or due to recognition that the stocks are intermingled across borders.

To explore these potential differences, we construct two different subsamples by utilizing information from the Sea Around Us dataset (Pauly and Zeller, 2015; Zeller et al., 2016) on whether the access agreement between countries $s$ and $d$ is reciprocal or not. Of the 14,571 country-pair-year observations with at least one kind of agreement, 11,745 observations had at least a non-reciprocal agreement and the remaining 2,826 only have a reciprocal agreement. In the first subsample, we only include countries that ever had a non-reciprocal access agreement and ever had trade in fish products with any other country in period 1962-2000. This sample has 170,644 observations with $6.9 \%$ having a non-reciprocal agreement. Note that even though our sub-sample includes all countries that ever had a non-reciprocal fishery agreement, there are country-pair-year observations with a current reciprocal agreement as some countries do have both types of agreements. In this specification, the observations with a reciprocal agreement are coded as zeros, thus, we compare observations with non-reciprocal agreements to observations with reciprocal ones and observations with no agreements. The results of this estimation are reported in the third column of Table 4.

Next we consider a sample of all countries that ever had a reciprocal access agreement, as well as a fish trade relationship with any country. This sample has 133,877 observations 
with $2.1 \%$ having a reciprocal agreement. ${ }^{22}$ The results of this estimation are reported in the last column of Table 4 .

We do find that the results are very different for these two sub-samples. A notable difference is that comparative fishing advantage seems to play an important role only for non-reciprocal agreements. Our estimations show that the coefficient on destination country stock status is now negative and statistically significant for non-reciprocal agreements. In contrast, for reciprocal agreements the coefficients on stock status for destination and source countries are both positive, statistically significant, and similar in magnitude. Hence, the difference in stock status is an important component of non-reciprocal agreements, whereas similarity is important for reciprocal agreements. There is also an important distinction in the role of fishing capacity. For non-reciprocal agreements, a larger fishing capacity of the destination country is an important indicator, while for reciprocal agreements, the coefficients on neither the source nor destination capacity are statistically significant.

There are also notable differences in the role of the gravity factors. For non-reciprocal agreements, the coefficient on GDP per capita is only statistically significant for the destination country. In contrast, for reciprocal agreements, coefficients on GDP per capita for both source and destination country are positive, statistically significant and similar in magnitude. This suggests that reciprocal access agreements are signed by countries that have similar high income per capita levels, while in the non-reciprocal agreements the source countries are from a spectrum of income levels.

With respect to distance variables, a larger physical distance between countries reduces the probability of any agreement but the magnitude of this effect is almost twice as large for non-reciprocal ones. Sharing a maritime border increases the probability of either type of agreement and the magnitude of the effect is more than twice as large for reciprocal agreements. Sharing a land border negatively affects non-reciprocal agreements but positively affects reciprocal agreements. Together these physical closeness results suggest contiguity of land or sea is extremely important for reciprocal relationships, perhaps more indicative of shared stocks or industries.

Cultural closeness characteristics such as sharing a common legal origin, religion, having a common colonist and being part of the same free trade agreement also have differing impacts. For example, having a common legal origin has a positive and significant effect

\footnotetext{
${ }^{22}$ The observations with a non-reciprocal agreement are coded as zeros in this specification, thus, we compare observations with reciprocal agreements to observations with non-reciprocal ones and observations with no agreements.
} 
only for reciprocal agreements, which provides further evidence that reciprocal agreements are signed between countries with similar economic environment. One having been a colony of the other has a positive coefficient for both types of agreements but having a common colonist or sharing a religion are only positively associated with non-reciprocal agreements suggesting that historical similarities might be also driving non-reciprocal agreements, not just the present circumstances.

To summarize, our evidence suggests that indeed reciprocal and non-reciprocal agreements have different motivations. Non-reciprocal agreements are mostly driven by a pattern of comparative advantage in fishing, whereas reciprocal agreements are signed between contiguous countries with similar economic environments.

\subsection{Results: International Fisheries Trade Incidence}

In this section we estimate Equation 1 with the incidence of trade, $T_{s d t}$, as the dependent variable.

\section{Trade: Baseline Specification}

The coefficients and marginal effects for the baseline estimation are reported in the first two columns of Table 5. Similar to the results for access agreements, the coefficient on fish stock status in the source country is positive and statistically significant. As the overall probability of a country-pair-year observation having trade is $20.1 \%$, the 0.1564 marginal effect of the mean tropic level of the source country rising by one increases the probability of trade by $77.8 \%$. The notable difference is that the sign on the coefficient of destination country stock status is now negative, that is, destination countries with a lower fish stock status are more likely to import fish products.

With respect to fishing capacity, the coefficient for the source country is positive while the coefficient for the destination country is negative, and both coefficients are statistically significant at $1 \%$ level. That is, a larger fishing capacity of the source country and a lower capacity of the destination country increases the probability of trade. These results on the pattern of fishing comparative advantage and fish exports are in line with our Empirical Prediction 2(a).

Examining the importance of gravity factors, we find that the coefficients on GDP per capita for source and destination countries are both positive, which supports our predictions 
regarding economic size. ${ }^{23}$

The results on our measures of distance costs between two countries yield interesting contrasts between agreements and trade. For some variables such as physical distance, having a common legal origin, common religion and having colonial ties in the past, the coefficients retain the signs as for agreements. The coefficient on the physical distance for trade incidence is a third smaller than for the agreement incidence. The higher sensitivity of agreements to larger physical distance is likely due to the frequency of trips. That is, trade in fish products can occur along with trade in other goods so the distance cost can be shared over multiple goods, whereas the distance cost of fish caught under an access agreement is only borne by the fish products.

Interestingly, unlike the results for agreements, sharing a maritime border does not have a statistically significant impact on the probability of trade in fish products. On the other hand, sharing a land border, a colonist, a currency, or a language now have statistically significant positive effects on trade incidence. A counter-intuitive estimation result is that being in the same FTA reduces the probability of fish trade between the pair of countries. De Benedictis and Taglioni (2011) suggest that the negative sign for the FTA indicator variable in a standard specification can be explained either by the existence of a significant time trend non-orthogonal to the FTA indicator or by a correlation between the FTA and bordersharing variables. In this case, the solution is to include time-variant exporter and importer fixed effects as well as time-invariant pair fixed effects. However, such a specification is not feasible for our analysis as we would then not be able to estimate the effects of all timevarying country-specific variables of our interest, such as fish stocks and fishing capacities, nor the time-invariant pair-specific variables, such as distance.

These results are supportive of our hypothesis that agreements and trade are acting, at least in part, as substitute pathways depending upon how important those characteristics are along each path.

\section{The European Union}

Recall the sharp drop in the number of fish trade pairs in 1984, due to member countries of the European Union reducing the number of trade partnerships outside of the EU, as depicted in Figure 2a. Next, we explore this issue in more detail, that is how being a member

\footnotetext{
${ }^{23}$ As the coefficient on population of the destination country is negative, we also estimate a version with GDP, rather than GDP per capita and population. In this estimation, the coefficient on economic size of the destination country is positive.
} 
of the European Union has implications for trade in fish. To do this we create an indicator variable, EU member, that equals one if at least one of the countries in the country-pair was an EU member in the relevant year. The estimation results of including this control variable are reported in the third column of Table 3. In contrast to the positive effect of the $E U C F P$ variable on access agreements, the coefficient of the $E U$ member variable is not statistically significant. ${ }^{24}$ This is likely to be due to the different specifications: in the agreements data, the $E U C F P$ variable was specifically controlling for whether at least one agreement between the country-pair in a particular year was due to the Common Fisheries Policy so the relationship between the dependent and independent variables was tighter. In the trade specification, we simply control for whether one of the countries in the pair was an EU member. In addition, we already control for importer and exporter fixed-effects, thus, the additional variation for the EU member variable to capture is limited.

\section{Historical Fishing Relationships}

Next, we explore how the existence of historical fishing relationship might have affected the incidence of fish exports after 1982 when UNCLOS has extended jurisdiction for the exclusive economic zone. We reestimate Equation 1 with an additional control variable Agt Prior $1982_{s d t}$, which is equal to one if there was an agreement between countries $s$ and $d$ prior to 1982 and if the observation year, $t$, is after 1982 and zero otherwise. The estimation results are reported in the final column in Table 5. Having had a fishery access agreement prior to 1982 is positively associated with having trade in fish products after 1982, although the magnitude of this effect only a third as large as for agreements. Considering the results from both the agreements and the trade specifications together, it seems that both trade and agreements have responded to the change in jurisdiction over historical fishing grounds.

\section{Reverse Causality and Sample Selection}

Similarly to our estimations for access agreements, our results for trade incidence might be affected by the reverse causality issue. Our prediction is that a higher stock status in the source country and a lower stock status in the destination country will make trade in fish products more likely. If the causality were running the other way, then exports of fish products would affect the fish stock status of the source country. However, in this case exporting fish

\footnotetext{
${ }^{24}$ Similarly to the estimation results for agreements, including the EU member indicator does not alter the other results.
} 
products will put downward pressure on the source country stocks, which would lead to a negative relationship between trade incidence and the source country stock status. Our results in Table 5 show that the observed relationship is, in fact, positive, which provides some support that the reverse causality problem is not large enough to overturn our results.

As with agreements, we investigate this issue further by reestimating our Equation using ten-year lags of stock status. The results are reported in the first column of Table 6 . We can see that the signs and statistical significance of the coefficients on stock status do not change, in fact the magnitude of the effect becomes larger for both destination and source countries stocks.

Next we address a potential problem of estimation bias due to a sample selection issue. Recall that our baseline sample includes all source and destination countries that ever had an agreement with any other country and ever had trade in fish products with any other country in the period 1962-2000. We reestimate Equation 1 using a larger sample which now includes all the countries that ever had any trade in fish products either as an exporter or as an importer, irrespective of having an agreement. This doubles the size of the sample as we recall from Figures $1 \mathrm{~b}$ and $2 \mathrm{~b}$ that there are more countries that ever traded than that ever had an agreement. The estimation results are reported in the second column in Table 6 . We can see that the results are similar in sign and statistical significance to the baseline specification so sample selection does not significantly affect our results.

\section{Reciprocal and Non-reciprocal Exports}

Finally we investigate how the motives for non-reciprocal trade relationships might be different from the motives for reciprocal relationships. We construct an indicator variable that is equal to one if there are both positive exports and positive imports of fish products from country $s$ to country $d$, and equal to zero otherwise. We reestimate Equation 1 for two different subsamples. In the first subsample, we include countries that ever had a non-reciprocal (one-way) trade relationship and ever had a fisheries access agreement with any other country in period 1962-2000. This sample contains 206,578 observations with $12.1 \%$ of them exhibiting positive, only one-way, exports. ${ }^{25}$ The results of this estimation are reported in the third column of Table 6 . In the second subsample, we include all countries that ever had reciprocal (two-way) trade in fish products, as well as a fishery access agreement with any country. This

\footnotetext{
${ }^{25}$ In this specification, all observations with a two-way trade are coded as zeroes. That is, we compare observations with non-reciprocal fish exports to observations with reciprocal exports and observations with no trade.
} 
sample includes 231,198 observations with $11.4 \%$ ever having had positive two-way exports. ${ }^{26}$ The results of this estimation are reported in the last column of Table 6 .

As with agreements, the nature of non-reciprocal and reciprocal trade seems to be different and the pattern of advantage in fishing plays a role only for non-reciprocal trade in fish. We find that a higher source country fish stock, a higher source country fishing capacity and a lower destination country fishing capacity have a statistically significant effect on countries having a non-reciprocal trade relationship. However, these variables do not influence the probability of reciprocal trade in fish products.

With respect to the gravity variables, we find that higher GDP per capita in both source and destination countries has a positive and statistically significant effect on probability of either type of trade relationship. Also, countries that are physically closer to each are more likely to engage in fish trade, both reciprocal and non-reciprocal. The cultural closeness characteristics of having a common legal system is positively associated with reciprocal trade but not non-reciprocal while having a common colonist is positively related to non-reciprocal trade but has no statistically significant impact upon reciprocal trade. These suggests that reciprocal trade occurs between more similar countries and is perhaps allowing more specific specialization than our annual, aggregate data is able to illuminate.

\section{Conclusion}

In this paper we build a unique dataset on international fisheries access agreements and trade to empirically examine the characteristics of pairs of countries that make agreements with each other and to compare this with the characteristics of countries that undertake fish trade. We distinguish between the contribution of two key factors that determine comparative advantage in fishing and consider standard gravity factors that affect international relationships.

We find that fish stock status influences the probability of fisheries agreements and trade similarly but that fishing capacity operates differently on these two types of fish flows. While some characteristics of distance affect both agreements and trade similarly, there are some interesting contrasts. For instance, sharing a maritime border is positively associated with agreements but land borders are what matter for trade, and cultural distance variables that affect the cost of transactions, such as currency and language, matter more for trade where

\footnotetext{
${ }^{26}$ In this specification, all observations with one-way exports are coded as zeroes.
} 
these transactions are more numerous.

Our results suggest that the usual suspects from a popular perspective, resource abundance and fishing capacity, do play a role in characterizing which countries make agreements with each other, but that they form only part of the story. Including in the analysis the standard factors from a trade perspective, economic size and closeness, and considering the alternative pathway of trade, has meant that we can shed a different light upon who makes access agreements with whom.

In our analysis, we are unable to consider the terms of fishery access agreements due to data limitations. Future work considering the most appropriate options for countries with abundant fish stocks but lower fishing capacity to reap the gains from their resources would be rewarding and important. 


\section{References}

Alavi, Rokiah. 2009. "Sanitary standards in the EU: The impact on Malaysian fishing industry." Journal of Economic Cooperation and Development 30(4):51-86.

Anderson, James E. and Eric van Wincoop. 2003. "Gravity with gravitas: A solution to the border puzzle." American Economic Review 93(1):170-192.

Arthur, Robert, Timothy W. Bostock, Lester D. Clark, Stephen Cunningham, Philip John Major, Tabitha Mallory, Tom McClurg, Gordon Munro, Mohamed Rouchdi, Suzannah Walmsley and James E. Wilen. 2014. Trade in fishing services: Emerging perspectives on foreign fishing arrangements. Environment and natural resources global practice discussion paper 1 World Bank Group, Washington, DC.

Asche, Frank, Marc F. Bellemare, Cathy Roheim, Martin D. Smith and Sigbjorn Tveteras. 2015. "Fair enough? Food security and the international trade of seafood." World Development 67:151-160.

Baldwin, Richard and James Harrigan. 2011. "Zeros, quality, and space: Trade theory and trade evidence." American Economic Journal: Microeconomics 3(2):60-88.

Bonfil, Ramon, Gordon R. Munro, U. Rashid Sumaila, Hreidar Valtysson, Miriam Wright, Tony Pitcher, David Preikshot, Nigel Haggan and Daniel Pauly. 1998. Distant water fleets: An ecological, economic and social assessment. Technical report Fisheries Centre Research Reports.

Clark, Colin W. and Gordon R. Munro. 2003. Fishing Capacity and Resource Management Objectives. In Measuring capacity in fisheries, FAO Fisheries Technical Paper 445, ed. Sean Pascoe and Dominique Greboval. FAO.

Claus, Simon, Nathalie De Hauwere, Bart Vanhoorne, Francisco Souza Dias, Paula Oset Garcia, Francisco Hernandez and Jan Mees (Flanders Marine Institute). 2014. "Maritime Boundaries Geodatabase, version 8." www.marineregions.org.

Convention on Biodiversity. 2004. "Annex I, decision VII/30. The 2020 biodiversity target: A framework for implementation. Decisions from the seventh meeting of the Conference of the Parties of the Convention on Biological Diversity, Kuala Lumpur, 9-10 and 27 February 2004.". 
De Benedictis, Luca and Daria Taglioni. 2011. The gravity model in international trade. In The trade impact of European Union preferential policies: An analysis through gravity models, ed. Luca De Benedictis and Luca Salvatici. Springer pp. 55-89.

Disdier, Anne-Celia and Stephan Marette. 2010. "The combination of gravity and welfare approaches for evaluating non-tariff measures." American Journal of Agricultural Economics $92(3): 713-726$.

Erhardt, Tobias. 2016. "Three essays on trade and the environment." PhD diss., School of Business and Economics, University of Basel.

European Commission. 2016. "Bilateral agreements with countries outside the EU." http://ec.europa.eu/fisheries/cfp/international/agreements.

European Communities. 1981. "Council Regulation (EEC) No 3796/81 on the common organization of the market in fishery products." Official Journal of the European Communities L 379, 31 December 1981.

European Communities. 1983. "Council Regulation (EEC) No 170/83 establishing a Community system for the conservation and management of fishery resources." Official Journal of the European Communities L 24, 27 January 1983.

FAO. 2016. "The State of World Fisheries and Aquaculture 2016. Contributing to food security and nutrition for all." Food and Agriculture Organisation of the United Nations, Rome.

Feenstra, Robert C., Robert E. Lipsey, Haiyan Deng, Alyson C. Ma and Hengyong Mo. 2004. World trade flows: 1962-2000. Working Paper 11040 NBER.

Forum Fisheries Agency. 2016. "US, Pacific forge ahead with fisheries treaty." www.ffa.int/node/1832.

Gordon, H.S. 1954. "The Economic Theory of a Common-Property Resource: The Fishery." Journal of Political Economy 62:124-142.

Greenpeace. 2012. "Fair Fisheries." www.greenpeace.org/international/en/campaigns/oceans/fairfisheries/. 
He, Chenyi, Kwamena K. Quagrainie and H. Holly Wang. 2013. "Determinants of shrimp importation into the USA: an application of an augmented gravity model." Journal of Chinese Economic and Business Studies 11:219-228.

Head, Keith and Thierry Mayer. 2014. Gravity Equations: Workhorse, Toolkit, and Cookbook. In Handbook of International Economics, Volume 4, ed. Gita Gopinath, Elhanan Helpman and Kenneth Rogoff. Elsevier B.V., Amsterdam pp. 1-740.

Head, Keith, Thierry Mayer and John Ries. 2010. "The erosion of colonial trade linkages after independence." Journal of International Economics 81(1):1-14.

Helpman, Elhanan, Marc Melitz and Yona Rubinstein. 2008. "Estimating trade flows: Trading partners and trading volumes." Quarterly Journal of Economics 123(2):441-487.

Hoshino, Eriko, Caleb Gardner, Sarah Jennings and Klaas Hartmann. 2015. "Price relationships for imported abalone in Japan." Marine Resource Economics 30(2):179-192.

Kurlansky, Mark. 1998. Cod: A biography of the fish that changed the world. Penguin.

Le Manach, Frederic, Christian Chaboud, Duncan Copeland, Philippe Cury, Didier Gascuel, Kristin M. Kleisner, Andre Standing, U. Rashid Sumaila, Dirk Zeller and Daniel Pauly. 2013. "European Union's public fishing access agreements in developing countries." PLoS ONE 8(11):1-10.

Mallory, Tabitha G. 2013. "China's distant water fishing industry: Evolving policies and implications." Marine Policy 38:99-108.

McWhinnie, Stephanie F. 2009. "The Tragedy of the commons in international fisheries: An empirical examination." Journal of Environmental Economics and Management 57(3):321333.

Nichols, Rachel, Satoshi Yamazaki, Sarah Jennings and Reg A. Watson. 2015. "Fishing access agreements and harvesting decisions of host and distant water fishing nations." Marine Policy 54:77-85.

Norman-Lopez, Ana, Sean Pascoe, Olivier Thebaud, Ingrid van Putten, James Innes, Sarah Jennings, Alistair Hobday, Bridget Green and Eva Plaganyi. 2013. "Price integration in the Australian rock lobster industry: Implications for management and climate change adaptation." Australian Journal of Agricultural and Resource Economics 58:43-59. 
Pacific Salmon Commission. 2016. www.psc.org.

Pauly, Daniel and Dirk Zeller. 2015. "Sea Around Us concepts, design and data." www.seaaroundus.org.

Pauly, Daniel, Villy Christensen, Johanne Dalsgaard, Rainer Froese and Francisco Jr. . 1998. "Fishing down marine food webs." Science 279:860-863.

Prickett, Nigel. 2002. "The archaeology of New Zealand shore whaling.".

Psihoyos, Louie. 2009. "The Cove." thecovemovie.com.

Rabbani, Abed G., Madan Mohan Dey and Kehar Singh. 2011. "Determinants of catfish, basa and tra importation into the USA: An application of an augmented gravity model." Aquaculture Economics and Management 15:230-244.

Rus, Horatiu A. 2012. "Transboundary marine resources and trading neighbours." Environmental and Resource Economics 53:159-184.

Schaefer, M.B. 1957. "Some Considerations of Population Dynamics and Economics in Relation to the Management of the Commercial Marine Fisheries." Journal of the Fisheries Research Board of Canada 14:669-681.

Tinbergen, Jan. 1962. Shaping the World Economy; Suggestions for an International Economic Policy. Twentieth Century Fund, New York.

Tveteras, Sigbjorn and Frank Asche. 2008. "International fish trade and exchange rates: An application to the trade with salmon and fishmeal." Applied Economics 40:1745-1755.

United Nations. 1982. United Nations Convention on the Law of the Sea. Doc. a/conf. 62/122 United Nations.

United States of America. 2016. "Treaty on fisheries between the governments of certain Pacific Island states and the government of the United States of America.".

Watson, Reg A., Rachel Nichols, Vicky W.Y. Lam and U. Rashid Sumaila. 2017. "Global seafood trade flows and developing economies: Insights from linking trade and production." Marine Policy 82:41-49.

Yunus, Mohammad. 2009. "EU ban, HACCP compliance and shrimp exports from Bangladesh." The Bangladesh Development Studies 32(3):41-57. 
Zeller, Dirk, M.L. Deng Palomares, Arash Tavakolie, Melanie Ang, Dyhia Belhabib, William W.L. Cheung, Vicky W.Y. Lam, Eric Sy, Gordon Tsui, Kyrstn Zylich and Daniel Pauly. 2016. "Still catching attention: Sea Around Us reconstructed global catch data, their spatial expression and public accessibility." Marine Policy 70:145 - 152. 


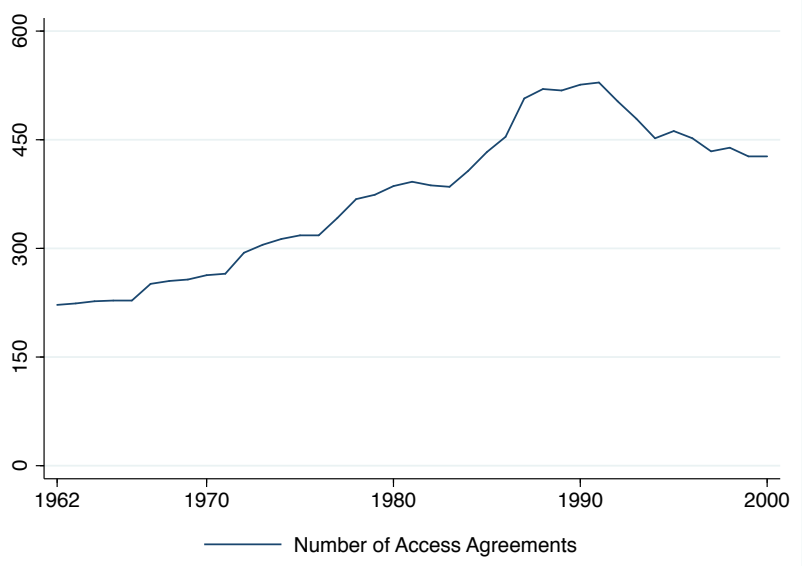

(a) Number of Access Agreements

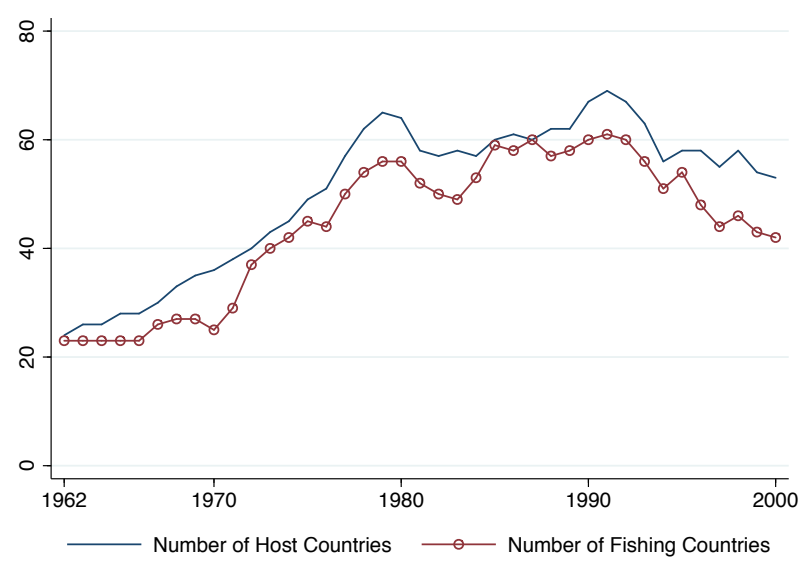

(b) Number of Countries in Agreements

Figure 1: Access Agreements 1962-2000

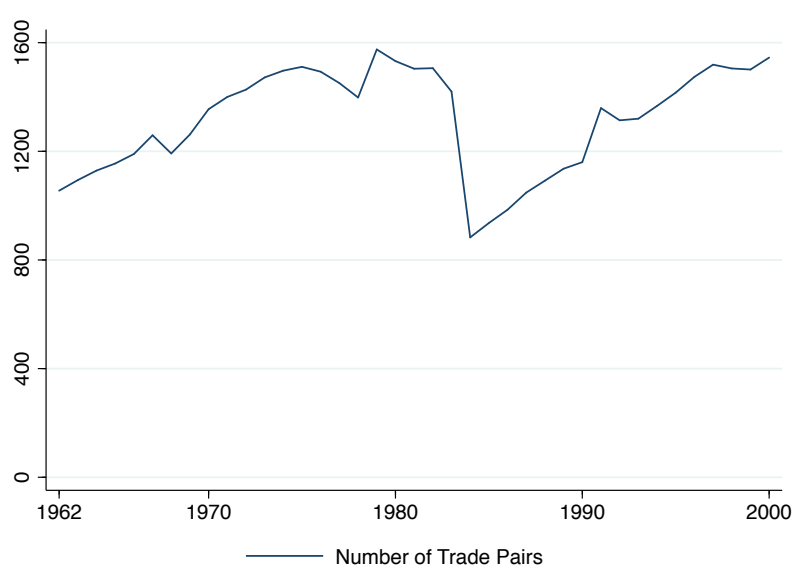

(a) Trade Incidence Over Time

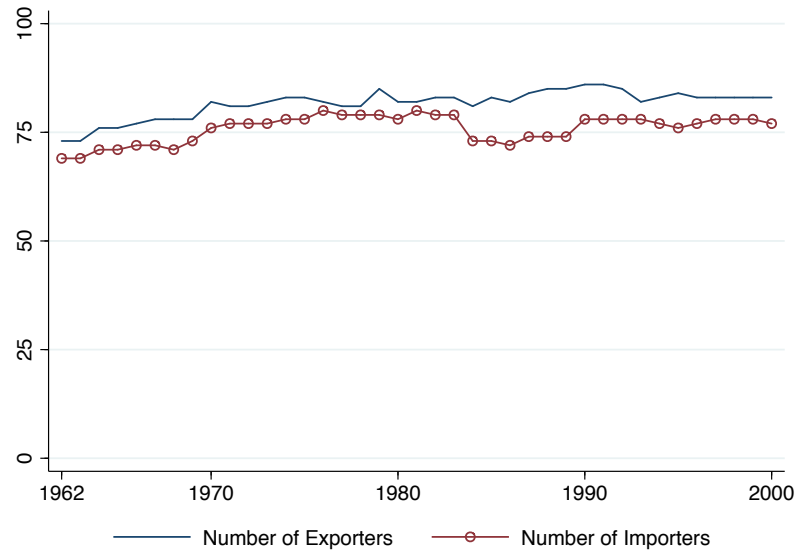

(b) Number of Exporting and Importing Countries

Figure 2: Fish Trade 1962-2000 
Table 1: List of Variables

\section{Dependent variables}

$A_{\text {sdt }}$

$T_{s d t}$

$=1$ if there is an agreement between $s$ and $d$ in year $t$

$=1$ if there are positive exports of fish products from $s$ to $d$ in year $t$

\section{Explanatory variables: advantage in fishing}

Stock $_{i t} \quad$ the mean trophic level of country $i$ in year $t-1$

Capacity $_{i t} \quad$ total tonnes caught by country $i$ in year $t-10$

\section{Explanatory variables: gravity}

GDP/ capita $_{i t} \quad$ GDP per capita of country $i$ in year $t-1$, in current US\$

Population $_{i t} \quad$ population of country $i$ in year $t-1$, in millions

Maritime Border $_{s d t}=1$ if $s$ and $d$ share a maritime border

Land Border $_{d s t} \quad=1$ if $s$ and $d$ share a land border

Distance $_{s d} \quad$ population weighted bilateral distance between $s$ and $d$, in $\mathrm{km}$

Legal $_{s d} \quad=1$ if $s$ and $d$ have common legal origins

Religion $_{s d} \quad$ sum of the products of the shares of Catholics, Protestants and Muslims in $s$ and $d$; between 0 and 1

Common Colonist $_{s d}=1$ if $s$ and $d$ had a common colonizer post 1945

Colony $_{s d} \quad=1$ if $s$ and $d$ ever in colonial relationship

$F T A_{s d t} \quad=1$ if $s$ and $d$ are in the same free trade area (using fta_wto measure)

Currency Union $_{\text {sdt }} \quad=1$ if $s$ and $d$ have a common currency

Language $_{s d} \quad=1$ if $s$ and $d$ have a common official or primary language 
Table 2: Summary Statistics: Means and Standard Deviations

\begin{tabular}{|c|c|c|c|c|c|}
\hline & Agreement & No Agreement & Trade & No Trade & Total \\
\hline \multirow[t]{2}{*}{ Agreement Incidence } & 1 & 0 & 0.192 & 0.023 & 0.057 \\
\hline & $(0)$ & $(0)$ & $(0.394)$ & $(0.149)$ & $(0.232)$ \\
\hline \multirow[t]{2}{*}{ Trade Incidence } & 0.679 & 0.172 & 1 & 0 & 0.201 \\
\hline & $(0.467)$ & $(0.377)$ & $(0)$ & $(0)$ & $(0.401)$ \\
\hline \multirow[t]{2}{*}{ Stock Source } & 3.528 & 3.501 & 3.493 & 3.505 & 3.503 \\
\hline & $(0.199)$ & $(0.266)$ & $(0.240)$ & $(0.268)$ & $(0.263)$ \\
\hline \multirow[t]{2}{*}{ Stock Destination } & 3.506 & 3.501 & 3.490 & 3.504 & 3.501 \\
\hline & $(0.192)$ & $(0.296)$ & $(0.233)$ & $(0.304)$ & $(0.291)$ \\
\hline \multirow{2}{*}{$\begin{array}{l}\text { Capacity Source } \\
\text { (thou tonnes) }\end{array}$} & 1277.6 & 1055.4 & 2052.0 & 820.8 & 1068.0 \\
\hline & $(1900.7)$ & $(2166.9)$ & $(2846.2)$ & $(1860.6)$ & $(2153.3)$ \\
\hline \multirow{2}{*}{$\begin{array}{l}\text { Capacity Destination } \\
\text { (thou tonnes) }\end{array}$} & 1906.4 & 998.0 & 1751.4 & 873.4 & 1049.7 \\
\hline & $(2824.3)$ & $(2123.4)$ & $(2750.9)$ & $(1971.8)$ & $(2179.5)$ \\
\hline \multirow{2}{*}{$\begin{array}{l}\text { GDP / capita } \\
\text { Source }\end{array}$} & 9393.2 & 3448.6 & 6193.5 & 3182.0 & 3786.7 \\
\hline & $(9377.6)$ & $(6190.6)$ & $(8290.8)$ & $(5896.2)$ & $(6560.6)$ \\
\hline \multirow{2}{*}{$\begin{array}{l}\text { GDP/capita } \\
\text { Destination }\end{array}$} & 10025.7 & 3486.1 & 7762.9 & 2877.1 & 3858.1 \\
\hline & $(9507.6)$ & $(6284.6)$ & $(9193.7)$ & $(5466.4)$ & $(6684.7)$ \\
\hline \multirow{2}{*}{$\begin{array}{l}\text { Population Source } \\
\text { (millions) }\end{array}$} & 38.89 & 46.58 & 67.59 & 40.76 & 46.15 \\
\hline & $(94.91)$ & $(139.7)$ & $(163.2)$ & $(129.7)$ & $(137.5)$ \\
\hline \multirow{2}{*}{$\begin{array}{l}\text { Population Destination } \\
\text { (millions) }\end{array}$} & 58.30 & 46.79 & 54.55 & 45.66 & 47.45 \\
\hline & $(143.7)$ & $(142.1)$ & $(128.8)$ & $(145.3)$ & $(142.2)$ \\
\hline \multirow{2}{*}{$\begin{array}{l}\text { Distance } \\
\text { (popn weighted km) }\end{array}$} & 3294.1 & 8178.3 & 6718.5 & 8197.4 & 7900.5 \\
\hline & $(2980.4)$ & $(4298.2)$ & $(4239.9)$ & $(4368.0)$ & $(4382.8)$ \\
\hline \multirow[t]{2}{*}{ Maritime Border } & 0.217 & 0.024 & 0.082 & 0.023 & 0.035 \\
\hline & $(0.412)$ & $(0.154)$ & $(0.274)$ & $(0.151)$ & $(0.184)$ \\
\hline \multirow[t]{2}{*}{ Land Border } & 0.116 & 0.017 & 0.041 & 0.018 & 0.023 \\
\hline & $(0.320)$ & $(0.129)$ & $(0.198)$ & $(0.132)$ & $(0.148)$ \\
\hline \multirow[t]{2}{*}{ Legal } & 0.377 & 0.397 & 0.383 & 0.399 & 0.396 \\
\hline & $(0.485)$ & $(0.489)$ & $(0.486)$ & $(0.490)$ & $(0.489)$ \\
\hline \multirow[t]{2}{*}{ Religion } & 0.269 & 0.160 & 0.192 & 0.160 & 0.166 \\
\hline & $(0.291)$ & $(0.230)$ & $(0.264)$ & $(0.227)$ & $(0.235)$ \\
\hline \multirow[t]{2}{*}{ Colony } & 0.089 & 0.018 & 0.082 & 0.007 & 0.022 \\
\hline & $(0.284)$ & $(0.132)$ & $(0.274)$ & $(0.082)$ & $(0.146)$ \\
\hline \multirow[t]{2}{*}{ Common Colonist } & 0.019 & 0.065 & 0.022 & 0.072 & 0.062 \\
\hline & $(0.137)$ & $(0.246)$ & $(0.147)$ & $(0.259)$ & $(0.242)$ \\
\hline \multirow[t]{2}{*}{ FTA } & 0.358 & 0.014 & 0.098 & 0.018 & 0.034 \\
\hline & $(0.479)$ & $(0.118)$ & $(0.297)$ & $(0.132)$ & $(0.180)$ \\
\hline \multirow[t]{2}{*}{ Currency Union } & 0.017 & 0.012 & 0.014 & 0.011 & 0.012 \\
\hline & $(0.129)$ & $(0.107)$ & $(0.115)$ & $(0.106)$ & $(0.108)$ \\
\hline \multirow[t]{2}{*}{ Language } & 0.110 & 0.167 & 0.173 & 0.162 & 0.164 \\
\hline & $(0.313)$ & $(0.373)$ & $(0.378)$ & $(0.368)$ & $(0.370)$ \\
\hline Observations & 14571 & 241592 & 51437 & 204726 & 256163 \\
\hline
\end{tabular}


Table 3: Fisheries Access Agreements I

\begin{tabular}{|c|c|c|c|c|}
\hline & $\overline{\mathrm{Pr}(\text { Agreement })}$ & "Marginal Effects & 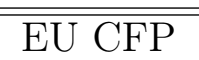 & 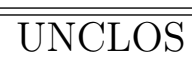 \\
\hline Log Stock & $1.9449^{* * *}$ & $0.0036^{* * *}$ & $2.0763^{* * *}$ & $2.2354^{* * *}$ \\
\hline Source & $(0.4082)$ & $(0.0010)$ & $(0.4077)$ & $(0.4678)$ \\
\hline Log Stock & $0.7822^{* *}$ & $0.0014^{* *}$ & $1.0410^{* * *}$ & $0.8075^{*}$ \\
\hline Destination & $(0.3699)$ & $(0.0007)$ & $(0.3699)$ & $(0.4350)$ \\
\hline Log Capacity & -0.0569 & -0.0001 & -0.0562 & $-0.0865^{*}$ \\
\hline Source & $(0.0410)$ & $(0.0001)$ & $(0.0422)$ & $(0.0465)$ \\
\hline Log Capacity & $0.0708^{* *}$ & $0.0001^{*}$ & $0.0684^{*}$ & $0.0805^{* *}$ \\
\hline Destination & $(0.0360)$ & $(0.0001)$ & $(0.0369)$ & $(0.0409)$ \\
\hline Log GDP/capita & $0.0973^{* *}$ & $0.0002^{* *}$ & $0.1058^{* *}$ & $0.0922^{*}$ \\
\hline Source & $(0.0442)$ & $(0.0001)$ & $(0.0437)$ & $(0.0499)$ \\
\hline Log GDP/capita & $0.2121^{* * *}$ & $0.0004^{* * *}$ & $0.2031^{* * *}$ & $0.2129^{* * *}$ \\
\hline Destination & $(0.0420)$ & $(0.0001)$ & $(0.0417)$ & $(0.0494)$ \\
\hline Log Population & $0.6173^{* * *}$ & $0.0011^{* * *}$ & $0.4401^{* * *}$ & $0.9127^{* * *}$ \\
\hline Source & $(0.1594)$ & $(0.0003)$ & $(0.1584)$ & $(0.1795)$ \\
\hline Log Population & $1.4010^{* * *}$ & $0.0026^{* * *}$ & $1.2119^{* * *}$ & $1.9118^{* * *}$ \\
\hline Destination & $(0.1975)$ & $(0.0005)$ & $(0.1941)$ & $(0.2400)$ \\
\hline Log Distance & $\begin{array}{c}-0.9381^{* * *} \\
(0.0500)\end{array}$ & $\begin{array}{c}-0.0017^{* * *} \\
(0.0003)\end{array}$ & $\begin{array}{c}-0.8088^{* * *} \\
(0.0533)\end{array}$ & $\begin{array}{c}-0.8294^{* * *} \\
(0.0450)\end{array}$ \\
\hline Maritime Border (d) & $\begin{array}{c}0.5423^{* * *} \\
(0.1195)\end{array}$ & $\begin{array}{l}0.0024^{* *} \\
(0.0011)\end{array}$ & $\begin{array}{c}0.5897^{* * *} \\
(0.1252)\end{array}$ & $\begin{array}{c}0.4137^{* * *} \\
(0.1071)\end{array}$ \\
\hline Land Border (d) & $\begin{array}{l}-0.2714 \\
(0.1680)\end{array}$ & $\begin{array}{c}-0.0003^{* *} \\
(0.0001)\end{array}$ & $\begin{array}{l}-0.1732 \\
(0.1680)\end{array}$ & $\begin{array}{l}-0.1777 \\
(0.1463)\end{array}$ \\
\hline Legal (d) & $\begin{array}{c}0.3113^{* * *} \\
(0.0720)\end{array}$ & $\begin{array}{c}0.0007^{* * *} \\
(0.0002)\end{array}$ & $\begin{array}{c}0.3765^{* * *} \\
(0.0709)\end{array}$ & $\begin{array}{c}0.3086^{* * *} \\
(0.0654)\end{array}$ \\
\hline Religion & $\begin{array}{c}0.4239^{* * *} \\
(0.1493)\end{array}$ & $\begin{array}{c}0.0008^{* * *} \\
(0.0003)\end{array}$ & $\begin{array}{l}0.3569^{* *} \\
(0.1488)\end{array}$ & $\begin{array}{c}0.4059^{* * *} \\
(0.1332)\end{array}$ \\
\hline Colony (d) & $\begin{array}{c}0.4930^{* * *} \\
(0.1204)\end{array}$ & $\begin{array}{l}0.0021^{* *} \\
(0.0010)\end{array}$ & $\begin{array}{c}0.6276^{* * *} \\
(0.1205)\end{array}$ & $\begin{array}{c}0.4353^{* * *} \\
(0.1082)\end{array}$ \\
\hline Common Colonist (d) & $\begin{array}{l}-0.0004 \\
(0.1890)\end{array}$ & $\begin{array}{l}-0.0000 \\
(0.0003)\end{array}$ & $\begin{array}{c}0.0308 \\
(0.1775)\end{array}$ & $\begin{array}{l}-0.0480 \\
(0.1678)\end{array}$ \\
\hline $\operatorname{FTA}(\mathrm{d})$ & $\begin{array}{c}0.5872^{* * *} \\
(0.0821)\end{array}$ & $\begin{array}{c}0.0029^{* * *} \\
(0.0010)\end{array}$ & $\begin{array}{c}0.4270^{* * *} \\
(0.0859)\end{array}$ & $\begin{array}{c}0.4069^{* * *} \\
(0.0820)\end{array}$ \\
\hline Currency Union (d) & $\begin{array}{c}-0.0553 \\
(0.1977)\end{array}$ & $\begin{array}{c}-0.0001 \\
(0.0003)\end{array}$ & $\begin{array}{c}-0.0795 \\
(0.2069)\end{array}$ & $\begin{array}{l}-0.1525 \\
(0.2062)\end{array}$ \\
\hline Language (d) & $\begin{array}{c}-0.2513^{* *} \\
(0.1068)\end{array}$ & $\begin{array}{c}-0.0004^{* * *} \\
(0.0001)\end{array}$ & $\begin{array}{c}-0.3192^{* * *} \\
(0.1062)\end{array}$ & $\begin{array}{c}-0.2421^{* * *} \\
(0.0929)\end{array}$ \\
\hline $\operatorname{EU~CFP~(d)~}$ & & & $\begin{array}{c}0.9984^{* * *} \\
(0.1608)\end{array}$ & \\
\hline Agt Prior 1982 (d) & & & & $\begin{array}{c}1.5316^{* * *} \\
(0.0809)\end{array}$ \\
\hline Constant & $\begin{array}{c}-11.882^{* * *} \\
(1.390)\end{array}$ & & $\begin{array}{c}-11.707^{* * *} \\
(1.364)\end{array}$ & $\begin{array}{c}-13.856^{* * *} \\
(1.595)\end{array}$ \\
\hline Observations & 256163 & 256163 & 256163 & 256163 \\
\hline Pseudo $R^{2}$ & 0.644 & 0.644 & 0.650 & 0.676 \\
\hline
\end{tabular}

Notes: Dependent Variable: Access Agreement (1) or Not (0).

Year, source and destination country controls are included but coefficients are not reported. Significance levels: $* 10 \% * * 5 \% * * * 1 \%$. Standard errors are clustered at the country-pair level. 
Table 4: Fisheries Access Agreements II

\begin{tabular}{|c|c|c|c|c|}
\hline & Lag Stock & Full Sample & Non-reciprocal & Reciproca \\
\hline Log Stock & $1.0812^{* * *}$ & & & \\
\hline Source t-10 & $(0.3778)$ & & & \\
\hline Log Stock & -0.1623 & & & \\
\hline Destination t-10 & $(0.4169)$ & & & \\
\hline Log Stock & & $2.0866^{* * *}$ & $1.1567^{* *}$ & $3.7871^{* * *}$ \\
\hline Source & & $(0.3914)$ & $(0.4692)$ & $(0.8761)$ \\
\hline Log Stock & & $1.0153^{* * *}$ & $-1.1119^{* * *}$ & $3.6270^{* * *}$ \\
\hline Destination & & $(0.3516)$ & $(0.4060)$ & $(0.8653)$ \\
\hline Log Capacity & -0.0304 & -0.0509 & -0.0561 & -0.1449 \\
\hline Source & $(0.0420)$ & $(0.0391)$ & $(0.0436)$ & $(0.0927)$ \\
\hline Log Capacity & $0.0665^{*}$ & $0.0771^{* *}$ & $0.1646^{* * *}$ & -0.1376 \\
\hline Destination & $(0.0366)$ & $(0.0346)$ & $(0.0383)$ & $(0.0933)$ \\
\hline Log GDP/capita & $0.1102^{* *}$ & $0.1135^{* * *}$ & -0.0480 & $0.3009^{* * *}$ \\
\hline Source & $(0.0443)$ & $(0.0432)$ & $(0.0523)$ & $(0.0853)$ \\
\hline Log GDP/capita & $0.2236^{* * *}$ & $0.2176^{* * *}$ & $0.2967^{* * *}$ & $0.2843^{* * *}$ \\
\hline Destination & $(0.0419)$ & $(0.0405)$ & $(0.0535)$ & $(0.0872)$ \\
\hline Log Population & $0.6489^{* * *}$ & $0.6152^{* * *}$ & $1.1457^{* * *}$ & -0.1912 \\
\hline Source & $(0.1599)$ & $(0.1551)$ & $(0.1875)$ & $(0.2872)$ \\
\hline Log Population & $1.4433^{* * *}$ & $1.4455^{* * *}$ & $1.4031^{* * *}$ & -0.1005 \\
\hline Destination & $(0.1974)$ & $(0.1932)$ & $(0.2725)$ & $(0.2883)$ \\
\hline \multirow{2}{*}{ Log Distance } & $-0.9389^{* * *}$ & $-0.9462^{* * *}$ & $-1.2610^{* * *}$ & $-0.6494^{* * *}$ \\
\hline & $(0.0498)$ & $(0.0445)$ & $(0.0689)$ & $(0.0790)$ \\
\hline \multirow[t]{2}{*}{ Maritime Border (d) } & $0.5390^{* * *}$ & $0.4149^{* * *}$ & $0.3879^{* *}$ & $0.9139^{* * *}$ \\
\hline & $(0.1195)$ & $(0.1078)$ & $(0.1744)$ & $(0.1628)$ \\
\hline \multirow[t]{2}{*}{ Land Border (d) } & -0.2682 & -0.1703 & $-0.5602^{* *}$ & $0.5373^{* *}$ \\
\hline & $(0.1678)$ & $(0.1597)$ & $(0.2463)$ & $(0.2300)$ \\
\hline \multirow[t]{2}{*}{ Legal (d) } & $0.3124^{* * *}$ & $0.3348^{* * *}$ & 0.0493 & $1.0447^{* * *}$ \\
\hline & $(0.0719)$ & $(0.0684)$ & $(0.0965)$ & $(0.1232)$ \\
\hline \multirow[t]{2}{*}{ Religion } & $0.4227^{* * *}$ & $0.4202^{* * *}$ & $0.9990^{* * *}$ & $-0.6233^{* * *}$ \\
\hline & $(0.1493)$ & $(0.1350)$ & $(0.1673)$ & $(0.2395)$ \\
\hline \multirow[t]{2}{*}{ Colony (d) } & $0.4952^{* * *}$ & $0.4620^{* * *}$ & $0.4699^{* *}$ & $0.8763^{* * *}$ \\
\hline & $(0.1201)$ & $(0.1080)$ & $(0.1839)$ & $(0.1867)$ \\
\hline \multirow[t]{2}{*}{ Common Colonist (d) } & 0.0008 & 0.0392 & $0.5743^{* *}$ & -0.0159 \\
\hline & $(0.1884)$ & $(0.1572)$ & $(0.2256)$ & $(0.2347)$ \\
\hline \multirow[t]{2}{*}{ FTA (d) } & $0.5810^{* * *}$ & $0.5572^{* * *}$ & $1.3079^{* * *}$ & $-0.5826^{* * *}$ \\
\hline & $(0.0819)$ & $(0.0803)$ & $(0.1047)$ & $(0.1906)$ \\
\hline \multirow[t]{2}{*}{ Currency Union (d) } & -0.0604 & -0.1090 & -0.0126 & -0.0696 \\
\hline & $(0.1971)$ & $(0.1775)$ & $(0.2513)$ & $(0.3053)$ \\
\hline \multirow[t]{2}{*}{ Language (d) } & $-0.2524^{* *}$ & $-0.2422^{* *}$ & $-0.3877^{* * *}$ & $-0.3655^{* *}$ \\
\hline & $(0.1065)$ & $(0.0970)$ & $(0.1419)$ & $(0.1795)$ \\
\hline \multirow[t]{2}{*}{ Constant } & $-10.240^{* * *}$ & $-12.612^{* * *}$ & $-8.632^{* * *}$ & $-20.424^{* * *}$ \\
\hline & $(1.436)$ & $(1.342)$ & $(1.665)$ & $(2.543)$ \\
\hline Observations & 256163 & 299389 & 170644 & 133877 \\
\hline Pseudo $R^{2}$ & 0.644 & 0.637 & 0.698 & 0.556 \\
\hline
\end{tabular}

Notes: Dependent Variable: Access Agreement (1) or Not (0); column 3 Non-reciprocal Agreement (1) or Not (0); column 4 Reciprocal Agreement (1) or Not (0).

Year, source and destination country controls are included but coefficients are not reported. Significance levels: $* 10 \% * * 5 \% * * * 1 \%$. Standard errors are clustered at the country-pair level. 
Table 5: Fisheries Trade I

\begin{tabular}{|c|c|c|c|c|}
\hline & $\bar{P} \operatorname{Pr}($ Trade $)$ & Marginal Effects & EU Member & $\overline{\text { UNCLOS }}$ \\
\hline Log Stock & $1.3244^{* * *}$ & $0.1564^{* * *}$ & $1.3244^{* * *}$ & $1.3054^{* * *}$ \\
\hline Source & $(0.2259)$ & $(0.0267)$ & $(0.2260)$ & $(0.2249)$ \\
\hline Log Stock & $-0.4241^{*}$ & $-0.0501^{*}$ & $-0.4241^{*}$ & $-0.4343^{*}$ \\
\hline Destination & $(0.2220)$ & $(0.0262)$ & $(0.2220)$ & $(0.2218)$ \\
\hline Log Capacity & $0.1193^{* * *}$ & $0.0141^{* * *}$ & $0.1193^{* * *}$ & $0.1274^{* * *}$ \\
\hline Source & $(0.0230)$ & $(0.0027)$ & $(0.0230)$ & $(0.0229)$ \\
\hline Log Capacity & $-0.0690^{* * *}$ & $-0.0081^{* * *}$ & $-0.0690^{* * *}$ & $-0.0685^{* * *}$ \\
\hline Destination & $(0.0222)$ & $(0.0026)$ & $(0.0222)$ & $(0.0220)$ \\
\hline Log GDP/capita & $0.1767^{* * *}$ & $0.0209^{* * *}$ & $0.1767^{* * *}$ & $0.1750^{* * *}$ \\
\hline Source & $(0.0255)$ & $(0.0030)$ & $(0.0255)$ & $(0.0254)$ \\
\hline Log GDP/capita & $0.4967^{* * *}$ & $0.0587^{* * *}$ & $0.4967^{* * *}$ & $0.4941^{* * *}$ \\
\hline Destination & $(0.0261)$ & $(0.0032)$ & $(0.0261)$ & $(0.0261)$ \\
\hline Log Population & $1.0876^{* * *}$ & $0.1284^{* * *}$ & $1.0877^{* * *}$ & $1.1373^{* * *}$ \\
\hline Source & $(0.1010)$ & $(0.0119)$ & $(0.1011)$ & $(0.1008)$ \\
\hline Log Population & $-0.7894^{* * *}$ & $-0.0932^{* * *}$ & $-0.7894^{* * *}$ & $-0.7138^{* * *}$ \\
\hline Destination & $(0.0974)$ & $(0.0116)$ & $(0.0980)$ & $(0.0979)$ \\
\hline Log Distance & $\begin{array}{c}-0.5756^{* * *} \\
(0.0227)\end{array}$ & $\begin{array}{c}-0.0680^{* * *} \\
(0.0029)\end{array}$ & $\begin{array}{c}-0.5756^{* * *} \\
(0.0227)\end{array}$ & $\begin{array}{c}-0.5615^{* * *} \\
(0.0228)\end{array}$ \\
\hline Maritime Border (d) & $\begin{array}{l}-0.0893 \\
(0.0785)\end{array}$ & $\begin{array}{l}-0.0099 \\
(0.0081)\end{array}$ & $\begin{array}{l}-0.0893 \\
(0.0785)\end{array}$ & $\begin{array}{l}-0.1113 \\
(0.0788)\end{array}$ \\
\hline Land Border (d) & $\begin{array}{l}0.1844^{*} \\
(0.1087)\end{array}$ & $\begin{array}{c}0.0249 \\
(0.0166)\end{array}$ & $\begin{array}{c}0.1844^{*} \\
(0.1084)\end{array}$ & $\begin{array}{c}0.1915^{*} \\
(0.1083)\end{array}$ \\
\hline Legal (d) & $\begin{array}{l}0.0647^{* *} \\
(0.0319)\end{array}$ & $\begin{array}{l}0.0077^{* *} \\
(0.0039)\end{array}$ & $\begin{array}{l}0.0647^{* *} \\
(0.0319)\end{array}$ & $\begin{array}{l}0.0636^{* *} \\
(0.0317)\end{array}$ \\
\hline Religion & $\begin{array}{c}0.2417^{* * *} \\
(0.0646)\end{array}$ & $\begin{array}{c}0.0285^{* * *} \\
(0.0077)\end{array}$ & $\begin{array}{c}0.2417^{* * *} \\
(0.0646)\end{array}$ & $\begin{array}{c}0.2336^{* * *} \\
(0.0644)\end{array}$ \\
\hline Colony (d) & $\begin{array}{c}0.7859^{* * *} \\
(0.0725)\end{array}$ & $\begin{array}{c}0.1570^{* * *} \\
(0.0210)\end{array}$ & $\begin{array}{c}0.7859^{* * *} \\
(0.0725)\end{array}$ & $\begin{array}{c}0.7753^{* * *} \\
(0.0717)\end{array}$ \\
\hline Common Colonist (d) & $\begin{array}{c}0.2178^{* * *} \\
(0.0735)\end{array}$ & $\begin{array}{c}0.0298^{* * *} \\
(0.0115)\end{array}$ & $\begin{array}{c}0.2178^{* * *} \\
(0.0735)\end{array}$ & $\begin{array}{c}0.2095^{* * *} \\
(0.0730)\end{array}$ \\
\hline $\mathrm{FTA}(\mathrm{d})$ & $\begin{array}{c}-0.2603^{* * *} \\
(0.0673)\end{array}$ & $\begin{array}{c}-0.0254^{* * *} \\
(0.0053)\end{array}$ & $\begin{array}{c}-0.2603^{* * *} \\
(0.0660)\end{array}$ & $\begin{array}{c}-0.3626^{* * *} \\
(0.0713)\end{array}$ \\
\hline Currency Union (d) & $\begin{array}{c}0.4697^{* * *} \\
(0.0863)\end{array}$ & $\begin{array}{c}0.0778^{* * *} \\
(0.0188)\end{array}$ & $\begin{array}{c}0.4697^{* * *} \\
(0.0864)\end{array}$ & $\begin{array}{c}0.4739^{* * *} \\
(0.0868)\end{array}$ \\
\hline Language (d) & $\begin{array}{c}0.2009^{* * *} \\
(0.0456)\end{array}$ & $\begin{array}{c}0.0263^{* * *} \\
(0.0066)\end{array}$ & $\begin{array}{c}0.2009^{* * *} \\
(0.0456)\end{array}$ & $\begin{array}{c}0.2077^{* * * *} \\
(0.0454)\end{array}$ \\
\hline EU member $(d)$ & & & $\begin{array}{c}0.0000 \\
(0.0439)\end{array}$ & \\
\hline Agt Prior 1982 (d) & & & & $\begin{array}{c}0.4333^{* * *} \\
(0.0616)\end{array}$ \\
\hline Constant & $\begin{array}{c}-5.757^{* * *} \\
(0.762)\end{array}$ & & $\begin{array}{c}-5.757^{* * *} \\
(0.759)\end{array}$ & $\begin{array}{c}-6.113^{* * *} \\
(0.758)\end{array}$ \\
\hline Observations & 256163 & 256163 & 256163 & 256163 \\
\hline Pseudo $R^{2}$ & 0.510 & 0.510 & 0.510 & 0.512 \\
\hline
\end{tabular}

Notes: Dependent Variable: Trade Incidence (1) or Not (0).

Year, source and destination country controls are included but coefficients are not reported. Significance levels: ${ }^{*} 10 \% * * 5 \% * * * 1 \%$. Standard errors are clustered at the country-pair level. 
Table 6: Fisheries Trade II

\begin{tabular}{|c|c|c|c|c|}
\hline & Lag Stock & Full Sample & Non-reciprocal & $\overline{\text { Reciprocal }}$ \\
\hline Log Stock & $1.4841^{* * *}$ & & & \\
\hline Source t-10 & $(0.2293)$ & & & \\
\hline Log Stock & $-0.8451^{* * *}$ & & & \\
\hline Destination t-10 & $(0.2419)$ & & & \\
\hline Log Stock & & $0.9977^{* * *}$ & $1.6187^{* * *}$ & 0.4149 \\
\hline Source & & $(0.1672)$ & $(0.2551)$ & $(0.3153)$ \\
\hline Log Stock & & $-0.3253^{* *}$ & -0.2916 & -0.2946 \\
\hline Destination & & $(0.1590)$ & $(0.2558)$ & $(0.3143)$ \\
\hline Log Capacity & $0.1542^{* * *}$ & $0.1414^{* * *}$ & $0.1744^{* * *}$ & 0.0349 \\
\hline Source & $(0.0246)$ & $(0.0170)$ & $(0.0246)$ & $(0.0349)$ \\
\hline Log Capacity & $-0.0803^{* * *}$ & $-0.0815^{* * *}$ & $-0.0988^{* * *}$ & 0.0027 \\
\hline Destination & $(0.0231)$ & $(0.0162)$ & $(0.0249)$ & $(0.0330)$ \\
\hline Log GDP/capita & $0.1742^{* * *}$ & $0.1222^{* * *}$ & $0.1637^{* * *}$ & $0.3412^{* * *}$ \\
\hline Source & $(0.0255)$ & $(0.0189)$ & $(0.0274)$ & $(0.0384)$ \\
\hline Log GDP / capita & $0.5022^{* * *}$ & $0.4900^{* * *}$ & $0.4588^{* * *}$ & $0.5728^{* * *}$ \\
\hline Destination & $(0.0260)$ & $(0.0201)$ & $(0.0282)$ & $(0.0392)$ \\
\hline Log Population & $1.0804^{* * *}$ & $0.9062^{* * *}$ & $1.2480^{* * *}$ & $0.5057^{* * *}$ \\
\hline Source & $(0.1014)$ & $(0.0724)$ & $(0.1135)$ & $(0.1448)$ \\
\hline Log Population & $-0.7642^{* * *}$ & $-0.4569^{* * *}$ & $-0.8361^{* * *}$ & -0.1932 \\
\hline Destination & $(0.0977)$ & $(0.0626)$ & $(0.1062)$ & $(0.1482)$ \\
\hline \multirow[t]{2}{*}{ Log Distance } & $-0.5767^{* * *}$ & $-0.6125^{* * *}$ & $-0.5210^{* * *}$ & $-0.7904^{* * *}$ \\
\hline & $(0.0227)$ & $(0.0163)$ & $(0.0279)$ & $(0.0308)$ \\
\hline \multirow[t]{2}{*}{ Maritime Border (d) } & -0.0898 & -0.0518 & -0.0695 & -0.1320 \\
\hline & $(0.0786)$ & $(0.0612)$ & $(0.1059)$ & $(0.1018)$ \\
\hline \multirow[t]{2}{*}{ Land Border (d) } & $0.1857^{*}$ & $0.1904^{* *}$ & 0.0309 & $0.2616^{*}$ \\
\hline & $(0.1087)$ & $(0.0823)$ & $(0.1289)$ & $(0.1501)$ \\
\hline \multirow[t]{2}{*}{ Legal (d) } & $0.0657^{* *}$ & $0.0670^{* * *}$ & 0.0205 & $0.1095^{* *}$ \\
\hline & $(0.0319)$ & $(0.0229)$ & $(0.0358)$ & $(0.0453)$ \\
\hline \multirow[t]{2}{*}{ Religion } & $0.2409^{* * *}$ & $0.2718^{* * *}$ & $0.2362^{* * *}$ & $0.2573^{* * *}$ \\
\hline & $(0.0646)$ & $(0.0456)$ & $(0.0738)$ & $(0.0987)$ \\
\hline \multirow[t]{2}{*}{ Colony (d) } & $0.7879^{* * *}$ & $0.6842^{* * *}$ & $0.6792^{* * *}$ & $1.1191^{* * *}$ \\
\hline & $(0.0727)$ & $(0.0543)$ & $(0.1041)$ & $(0.0857)$ \\
\hline \multirow[t]{2}{*}{ Common Colonist (d) } & $0.2189^{* * *}$ & $0.1487^{* * *}$ & $0.2175^{* * *}$ & 0.1686 \\
\hline & $(0.0734)$ & $(0.0469)$ & $(0.0770)$ & $(0.1157)$ \\
\hline \multirow[t]{2}{*}{ FTA (d) } & $-0.2652^{* * *}$ & $-0.1262^{* *}$ & $-0.4380^{* * *}$ & $-0.2743^{* * *}$ \\
\hline & $(0.0673)$ & $(0.0572)$ & $(0.0982)$ & $(0.0833)$ \\
\hline \multirow[t]{2}{*}{ Currency Union (d) } & $0.4715^{* * *}$ & $0.4133^{* * *}$ & $0.3857^{* * *}$ & $0.6508^{* * *}$ \\
\hline & $(0.0866)$ & $(0.0648)$ & $(0.0990)$ & $(0.1144)$ \\
\hline \multirow[t]{2}{*}{ Language (d) } & $0.2002^{* * *}$ & $0.2487^{* * *}$ & $0.2791^{* * *}$ & $0.1303^{* *}$ \\
\hline & $(0.0456)$ & $(0.0321)$ & $(0.0521)$ & $(0.0614)$ \\
\hline \multirow[t]{2}{*}{ Constant } & $-5.757^{* * *}$ & $-5.479^{* * *}$ & $-6.711^{* * *}$ & $-6.346^{* * *}$ \\
\hline & $(0.813)$ & $(0.554)$ & $(0.849)$ & $(1.130)$ \\
\hline Observations & 256163 & 506869 & 206578 & 231198 \\
\hline Pseudo $R^{2}$ & 0.511 & 0.517 & 0.444 & 0.649 \\
\hline
\end{tabular}

Notes: Dependent Variable: Trade Incidence (1) or Not (0); column 3 Non-reciprocal Trade (1) or Not (0); column 4 Reciprocal Trade (1) or Not (0).

Year, source and destination country controls are included but coefficients are not reported. Significance levels: ${ }^{*} 10 \% * * 5 \% * * * 1 \%$. Standard errors are clustered at the country-pair level. 